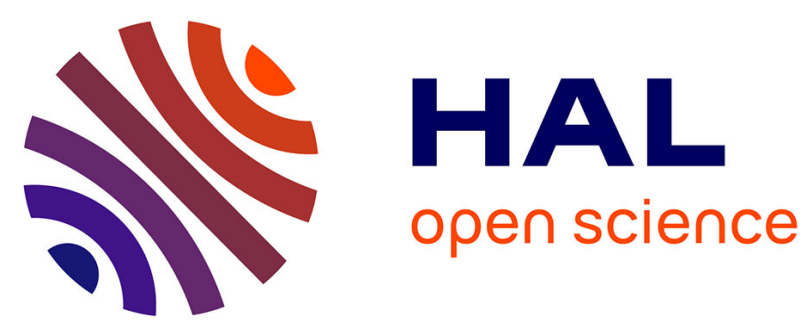

\title{
Relationship of Parasites and Pathologies to Contaminant Body Burden in Sentinel Bivalves: NOAA Status and Trends 'Mussel Watch' Program
}

\author{
Yungkul Kim, Eric N. Powell, Terry L. Wade, Bobby J. Presley
}

\section{- To cite this version:}

Yungkul Kim, Eric N. Powell, Terry L. Wade, Bobby J. Presley. Relationship of Parasites and Pathologies to Contaminant Body Burden in Sentinel Bivalves: NOAA Status and Trends 'Mussel Watch' Program. Marine Environmental Research, 2008, 65 (2), pp.101. 10.1016/j.marenvres.2007.09.003 . hal-00562992

\section{HAL Id: hal-00562992 https://hal.science/hal-00562992}

Submitted on 4 Feb 2011

HAL is a multi-disciplinary open access archive for the deposit and dissemination of scientific research documents, whether they are published or not. The documents may come from teaching and research institutions in France or abroad, or from public or private research centers.
L'archive ouverte pluridisciplinaire $\mathbf{H A L}$, est destinée au dépôt et à la diffusion de documents scientifiques de niveau recherche, publiés ou non, émanant des établissements d'enseignement et de recherche français ou étrangers, des laboratoires publics ou privés. 


\section{Accepted Manuscript}

Relationship of Parasites and Pathologies to Contaminant Body Burden in Sentinel Bivalves: NOAA Status and Trends 'Mussel Watch' Program

Yungkul Kim, Eric N. Powell, Terry L. Wade, Bobby J. Presley

PII:

S0141-1136(07)00114-6

DOI:

10.1016/j.marenvres.2007.09.003

Reference:

MERE 3143

To appear in:

Marine Environmental Research

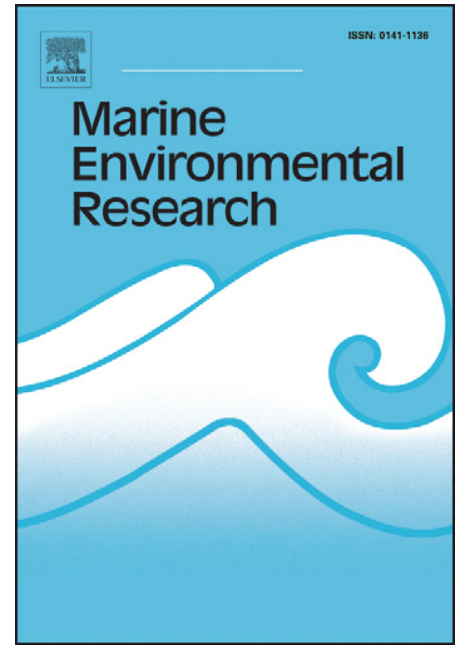

Received Date: 17 January 2007

Revised Date: $\quad 11$ September 2007

Accepted Date: $\quad 13$ September 2007

Please cite this article as: Kim, Y., Powell, E.N., Wade, T.L., Presley, B.J., Relationship of Parasites and Pathologies to Contaminant Body Burden in Sentinel Bivalves: NOAA Status and Trends 'Mussel Watch' Program, Marine Environmental Research (2007), doi: 10.1016/j.marenvres.2007.09.003

This is a PDF file of an unedited manuscript that has been accepted for publication. As a service to our customers we are providing this early version of the manuscript. The manuscript will undergo copyediting, typesetting, and review of the resulting proof before it is published in its final form. Please note that during the production process errors may be discovered which could affect the content, and all legal disclaimers that apply to the journal pertain. 


\title{
Relationship of Parasites and Pathologies to Contaminant Body Burden in Sentinel Bivalves: NOAA Status and Trends 'Mussel Watch' Program
}

\author{
Yungkul Kim ${ }^{1}$ \\ Eric N. Powell ${ }^{1}$ \\ Terry L. Wade ${ }^{2}$ \\ Bobby J. Presley ${ }^{3}$ \\ ${ }^{1}$ Haskin Shellfish Research Laboratory \\ Rutgers University \\ 6959 Miller Ave \\ Port Norris NJ 08349-3167 \\ ${ }^{2}$ Geochemical and Environmental Research Group \\ Texas A\&M University \\ 833 Graham Road \\ College Station, Texas 77845 \\ ${ }^{3}$ Department of Oceanography \\ Texas A\&M University \\ College Station, TX 77843
}

\begin{abstract}
The 1995-1998 database from NOAA's National Status and Trends 'Mussel Watch' Program was used to compare the distributional patterns of parasites and pathologies with contaminant body burdens. Principal components analysis (PCA) resolved five groups of contaminants in both mussels and oysters: one dominated by PAHs, one dominated by pesticides, and three dominated by metals. Metals produced a much more complex picture of spatial trends in body burden than did either the pesticides or PAHs. Contrasted to the relative simplicity of the
\end{abstract}


contaminant groupings, PCA exposed a suite of parasite/pathology groups with few similarities between the sentinel bivalve taxa. Thus, the relationship between parasites/pathologies and contaminants differs significantly between taxa despite the similarity in contaminant pattern. Moreover, the combined effects of many contaminants and parasites may be important, leading to complex biologicalcontaminant interactions with synergies both of biological and chemical origin.

Overall, correlations between parasites/pathologies and contaminants were more frequent with metals, frequent with pesticides, and less frequent with PAHs in mussels. In oysters, correlations with pesticides and metals were about equally frequent, but correlations with PAHs were still rare. In mytilids, correlations with metals predominated. Negative and positive correlations with metals occurred with about the same frequency in both taxa. The majority of correlations with pesticides were negative in oysters; not so for mytilids. Of the many significant correlations involving parasites, few involved single-celled eukaryotes or prokaryotes. The vast majority involved multi-cellular eukaryotes and nearly all of them either cestodes, trematode sporocysts, or trematode metacercariae. The few correlations for singlecelled parasites all involved proliferating protozoa or protozoa reaching high body burdens through transmission. The tendency for the larger or more numerous parasites to be involved suggests that unequal sequestration of contaminates between host and parasite tissue is a potential mediator. An alternative is that contaminants differentially affect parasites and their hosts by varying host susceptibility or parasite survival.

\section{Introduction}

Bivalve mollusks, such as mussels or oysters, are often used as sentinel organisms in contaminant monitoring programs (Phillips, 1977; Farrington et al., 1983; Green et al., 1989; Oliver and Fisher, 1999; Peterson, 2001). Bivalves are preferentially chosen as sentinel organisms for their ability to concentrate both metals and organic contaminants, their immobility, their limited ability to metabolize accumulated contaminants, their relatively wide distribution among habitats including those relatively heavily polluted, their abundance, their persistence, and their ease of collection, all of which make them good long-term integrators of the surrounding

environment (Phillips, 1977; O’Connor, 2002). 
The National Status and Trends 'Mussel Watch' Program has been monitoring contaminants of environmental concern since 1986 using bivalves as sentinel organisms (O'Connor, 2002). As Mussel Watch was designed to document the geographic distribution and temporal trends of contamination on a national scale, most sites were placed away from known point sources of contamination, poorly flushed industrial waterways, and pilings or metal buoys ( $\mathrm{O}^{\prime} \mathrm{C}$ onnor and Beliaeff, 1995; O'Connor, 1996). Sampling sites of an earlier Mussel Watch program (Goldberg et al., 1978, 1983) were, when possible, incorporated into the current Mussel Watch program (O’Connor, 1994).

Bivalves are presently collected every other year at a network of over 250 estuarine, lakeshore, and coastal locations along the U.S. Great Lakes, East, West, and Gulf coasts, with approximately half being visited during each annual sampling. Bivalve samples are analyzed for a variety of contaminants, including polycyclic aromatic hydrocarbons (PAHs), chlorinated pesticides, polychlorinated biphenyl (PCB) congeners, and major and trace elements. The Mussel Watch program also monitors the health of bivalve populations through the measurement of a variety of biological indices, including the prevalence and infection intensity of parasites, diseases, and tissue pathologies. The database thus obtained provides an opportunity to examine the relationships between parasites and pathologies on the one hand and contaminants on the other over a large geographic scale. The question of the relationship of contaminant body burden to parasites and pathologies is a complex one. Extrapolating from laboratory and field experimentation comparing parasites/pathologies with contaminant body burden to inferences at geographic scales has been difficult, due to the multiplicity of contaminants and parasites present in most environments and the limited geographic scale of most present-day databases inclusive of both variables.

Certain contaminants may increase parasite body burden favoring the propagation of parasites by excluding their natural predators, by reducing the resistance of their hosts, or by providing improved living conditions for their intermediate hosts (Möller, 1987). Contaminants may also interfere with parasite transmission or proliferation within hosts and thus reduce parasite burden (Lafferty and Kuris, 1999). The interaction of parasite and pathology with contaminant body burden is known 
primarily from controlled experiments. Barszcz et al. (1978) showed that host oysters exposed to crude oil had an increase in prevalence and intensity of infection by parasites, for example. Experimental studies by Pascoe and Cram (1977) and Boyce and Yamada (1977) showed that parasitized host fishes were more sensitive to $\mathrm{Cd}$ and $\mathrm{Zn}$, respectively. Ciliate epibionts increased host mortality in copepods exposed to PAHs (Puckett and Carman, 2002). In contrast, Khan and Kiceniuk (1983) found reduced infections of endoparasites in host fish exposed to crude oil. Whether the influence of the contaminant is directly on the parasite or mediated through the host is often unclear. The immune systems of host animals can be affected by contaminants (Sindermann, 1979; Rohde 1993), lowering the resistance of a host to a variety of parasites and increasing susceptibility to parasitic invasion and disease (Barszcz et al., 1978; Galli et al., 2001). Thulin (1989) pointed out that ectoparasites may be particularly sensitive to contaminants because they are in intimate contact with the external environment. Such parasites may be useful indicator organisms for early detection of adverse environmental effects (Thulin, 1989; MacKenzie et al., 1995; Galli et al., 2001).

The cause and effect explanation is most often the inference from observed correlations between parasite body burden and contaminant body burden. More recently, however, research has begun documenting an alternative explanation; the differential in body burden between parasites and their hosts may accrue from differential affinities for contaminant accumulation. Zimmerman et al. (1999), Sures et al. (1999), and Heinonen et al. (2001) provide salient examples. Although this potential is not yet included in models of contaminant body burden (e.g., Fraysse et al., 2002; Lee et al., 2002; Yamamoto et al., 2003), this realization leaves the obvious quandary for sentinel bivalves of whether parasite body burden by their tissue contribution influences the measured value for the host organism as a whole. Parasites may contribute a significant fraction of host biomass (e.g., Powell et al., 1999); thus, differential affinities could be important. This possibility offers one explanation for the frequent finding that contaminant body burden is non-normally distributed among individuals at a site, such that a few animals have unusually high contaminant body burdens (Boyden and Phillips, 1981; Daskalakis, 1996; Baldwin and Maher, 1997). Parasites tend to be skewed similarly in their distribution among hosts (Munger et al., 1989; Jones et al., 1991). 
The interaction between tissue pathology and contaminant body burden has also received some attention. Lowe et al. (1971) demonstrated that oysters exposed chronically to the pesticide DDT showed edema, lesions, and necrosis of the digestive tubule epithelium. Farley (1976) suggested the possible induction of epizootic neoplasia in bivalve molluses by carcinogenic compounds, such as pesticides (aldrin and dieldrin). Couch et al. (1979) found that oysters exposed to the carcinogen benzo $(a)$ pyrene showed inflammation of the connective tissue and proliferation of a cell resembling a sarcomatoid neoplasm. Wintermyer and Cooper (2003) and Svärdh and Johannesson (2002) provide additional examples. The distribution of pathologies in the field, however, can rarely be ascribed unequivocally to individual contaminants (Sindermann, 1983; Johnson et al., 1992; Landsberg, 1996). The establishment of parasitism and disease in aquatic populations is usually not due to a simple cause-and-effect relationship, but is dependent upon a complex interaction between organism and environment.

Thus, the use of parasites or pathologies as indicators of pollution stress has rarely been unequivocal (Möller, 1987). One important constraint is the rarity of surveys that include both contaminant and health assessments. Yevich and Barszcz (1983) correlated stations with high parasitism with stations with high PCB concentrations in host bivalves collected from natural coastal and estuarine waters in the first Mussel Watch Program. Wilson et al. (1992) and Kim et al. (2001) examined the relationship of contaminant body burden to health indices at Gulf of Mexico Mussel Watch sites. Johnson et al. (1992) and Schmidt et al. (2003) obtained promising results relating fish pathologies to contaminant burdens along the northeast coast of the U.S. and in the North Sea, respectively. The Mussel Watch Program is a unique multi-year study and the first of its kind that covers a large geographic area, multiple parasite species, and multiple contaminants. Here, we used the Mussel Watch database for 1995-1998 to examine the relationships between parasitism, pathology, and contaminant body burdens on regional scales with emphasis on identifying parasite assemblages and contaminant suites that resolve as significant relationships within the complex medley of potential contaminant/parasite/pathology combinations. Such relationships can provide the basis for mapping the results of individual cause and effect experiments to integrated population level processes observed in the field. 


\section{Materials and Methods}

\section{Species Sampled and Sample Collection}

The bivalve samples were collected annually from a network of sites established along the United States coastline. Bivalves were dredged or hand-picked in intertidal to shallow subtidal areas. Sampling targeted the largest animals available at each site. Each sampled site subsequently was assigned to one of 126 bays [see Lauenstein et al. (1997) for further details of site location]. A 'bay', as termed herein, represents all the sites in a single estuary, estuarine reach of a large estuary, or group of neighboring sites on an open coastline. Details on the allocation of sites to bays can be found in the Appendix of Kim and Powell (2006).

The introduced zebra mussel, Dreissena polymorpha, and quagga mussel, $D$. bugensis, were sampled at sites in the Great Lakes (Bays 1-10) and Hudson River (Bay 11). Zebra mussels were first discovered in the Great Lakes in 1988 (Hebert et al., 1989). Quagga mussels were found in 1991 (May and Marsden, 1992). Both likely were introduced from Europe in ship ballast water (Hebert et al., 1989). Both species spread rapidly throughout the Great Lakes system and then into the major river basins of the central and eastern U.S. (Griffiths et al., 1991; Strayer, 1991; Mills et al., 1996). Recently, the quagga mussel has displaced the zebra mussel in many areas (Stoeckmann, 2003). Rosenberg and Ludyanskiy (1994) discussed the taxonomy. Mussel Watch sites include all Great Lakes except Lake Superior (Lauenstein et al., 1997).

Mytilid mussel taxa were collected from the Northeast (Bays 12-36) and West (Bays 94-125) coasts, including Alaska. According to Hilbish et al. (2000), mussels collected on the East coast were Mytilus edulis sensu stricto, as $M$. edulis is the predominant species from central Maine south (Rawson et al., 2001) to Cape Hatteras (Wells and Gray, 1960). On the West coast, three mussel taxa were collected, $M$. californianus and two species referable to the $M$. edulis complex, $M$. galloprovincialis and $M$. trossulus. The taxonomic status of species in the $M$. edulis complex is uncertain (His et al., 2000). Mytilus californianus was collected at 31 sites mostly located at jetties, points or capes among the 58 total West coast sites

excluding Alaska (viz., 27 sites out of 36 in California, two sites among six in 
Oregon and two sites among 16 in Washington). Mytilus trossulus was collected at the vast majority of the more northern stations from Oregon to Alaska. Mytilus galloprovincialis was introduced into the eastern Pacific in the 1880s and now occurs from central California to Baja California, with some populations probably farther north (McDonald and Koehn, 1988; Koehn, 1991; Seed, 1992), including a population in Puget Sound established at least by 1988 (Wonham, 2004). Thus, $M$. galloprovincialis was collected at some California sites and may have been present in some Puget Sound collections. In addition, some central and northern California sites yielded mussels that probably were hybrids of $M$. galloprovincialis and $M$. trossulus (Hilbish et al., 2000).

Four oyster taxa were sampled, Crassostrea virginica, C. rhizophorae, C. gigas, and Dendostrea sandvichensis. Crassostrea virginica was sampled from coastal and estuarine areas of the Mid-Atlantic and southeast coasts (Bays 37-61) and the Gulf of Mexico (Bays 63-93). Crassostrea rhizophorae was collected in Puerto Rico (Bay 62), and C. gigas and D. sandvichensis were collected in Hawaii (Bay 126). Considerable disagreement exists as to the taxonomic status of $C$. virginica and $C$. rhizophorae (Newball and Carriker, 1983; Ladrón de Guevara et al., 1996; LaPègue et al., 2002), whereas C. gigas and D. sandvichensis are clearly distinct from the other two. In total, however, $C$. virginica was collected at 55 of 57 bays where oysters were collected.

To simplify discussion when referring to groups of these taxa, the following inclusive terms will be used: dreissenid in reference to the combination of $D$. bugensis and D. polymorpha; oyster jointly for C. virginica, C. rhizophorae, C. gigas, and D. sandvichensis; mytilid for $M$. edulis on the East coast and the combination of $M$. edulis, M. californianus, $M$. galloprovincialis, and $M$. trossulus on the West coast.

Except in the Great Lakes, the sampling sites were visited annually during winter months with each site occupied within 30 days of an annual target date (O'Connor, 1994). The sampling was done in winter to minimize the influence of reproduction on contaminant body burden as spawning may influence contaminant body burden (Jovanovich and Marion, 1987; Ellis et al., 1993; Baldwin and Mayer, 1997). In the Great Lakes, dreissenid mussels were collected in late August through 
September. Access to sampling sites in this area is difficult in winter as the Great Lakes are frequently frozen over during this period. As a consequence of sampling program design, analysis of the Mussel Watch dataset may be biased for those parasites that exhibit a strong seasonal cycle of infection intensity (e.g., Wallet and Lambert, 1986; Burreson and Ragone Calvo, 1996; Ford et al., 1999).

\section{Parasite/Pathology Quantification}

Tissue preparation followed the original NOAA Status and Trends protocols (Ellis et al., 1998a), as delineated by Kim and Powell (2006). Tissue samples were embedded in paraffin after dehydration and clearing, sectioned at $5 \mu \mathrm{m}$, and the sections stained in a pentachrome series (Ellis et al., 1998a).

Major tissue types examined included gill, mantle, gonad and gonoducts, digestive gland tubules, stomach/digestive gland, and connective tissue. For oysters, Perkinsus marinus was assayed by the more precise thioglycollate method (Powell and Ellis, 1998). All other parasites and pathologies were scored microscopically for intensity based on either a quantitative or semiquantitative scale. Quantitative scores were used for parasites, pathologies, and selected morphological conditions, including prokaryotic inclusions (rickettsia, chlamydia, etc.), ciliates, gregarines, nematodes, cestodes and metacercariae of trematodes, that could be tallied individually, following procedures described by Ellis et al. (1998b) and Kim et al. (2006). Ciliates were quantified by tissue type (viz., gill and digestive tract), as were the gregarines (viz., body, gill, and mantle). Each nematode cross-section observed was counted, although a single individual may be responsible for a number of tissue cross-sections. Certain tissue pathologies and tissue components were also quantified by direct counts, including cases of hemocytic infiltration that were scored separately as focal and diffuse (Kim and Powell, 2004), granulocytomas (Lowe and Moore, 1979), and ceroid bodies or pigment cells (Mackin, 1951; Stein and Mackin, 1955).

Some parasites and morphological conditions, such as ramifying trematode sporocysts and the disease-producing protozoans, P. marinus and Haplosporidium nelsoni, were assigned to semiquantitative scales depending on the intensity or extensiveness of the affected area. Definitions of scale values can be found in Ellis et 
al. (1998b) and Kim et al. (2006). A semiquantitative 0-to-4-point scale was used for ramifying trematode sporocysts of the families Fellodistomidae and Bucephalidae due to the extensiveness of infections and the difficulty in obtaining quantitative counts of the large branching sporocysts. Intensity of $P$. marinus infection was assigned using the semiquantitative 0 -to-5-point scale of Mackin as modified by Craig et al. (1989). Haplosporidium nelsoni infection intensity was scored on a 0-to-4-point scale of Kim et al. (2006) adapted from Ford and Figueras (1988). For each specimen examined, the presence of neoplasms and unusual digestive tubules was recorded. Abnormal gonadal development, characterized by unusual development at the base of the follicles and by presence of foreign cells and cellular debris in the follicles, was given a semiquantitative 0 -to-4-point score related to the spatial coverage of the condition (Kim et al., 2006). For digestive gland atrophy, a condition known to be caused by a variety of stressors most likely related to poor nutrition (Palmer, 1979; Winstead, 1995; Kim and Powell, 2004), the average degree of thinning of the digestive tubule walls was assigned a numerical rating on a 0 -to-4-point scale (Kim et al., 2006).

\section{Contaminant Analysis}

The contaminant analyses were carried out on pooled samples of twenty bivalves from each site using methods developed for the National Status and Trends Program (Lauenstein and Cantillo, 1993). Only data which passed rigorous QA/QC tests using blanks, spikes, and reference materials were used. In addition, each analytical laboratory successfully completed yearly QA/QC programs involving analysis of blind samples supplied by the National Institute of Standards and Technology and the National Research Council of Canada (Cantillo, 1992). Detailed descriptions of analytical methods for contaminant analyses can be found in Lauenstein and Cantillo (1998).

Oysters were sampled from the Housatonic River (Bay 37) and Port Jefferson (Bay 38), New York, in only one of the four years (1998). Consequently, data from these collections were deleted from analysis.

\section{Statistical Analysis}

Data for 24 contaminant categories were used for data analysis: 11 trace metals 
(Ag, As, Cd, Cr, Cu, Fe, Hg, Ni, Pb, Se and $\mathrm{Zn}$ ); the five PAHs normally present in highest concentration (naphthalene, phenanthrene, fluoranthene, pyrene and chrysene) and the sum of $24 \mathrm{PAH}$ compounds (total PAHs), as defined by Jackson et al. (1998); the sum of concentrations of DDT and its metabolites, DDE and DDD (total DDTs); four chlorinated pesticides other than DDT (aldrin, dieldrin, lindane and mirex); the sum of concentrations of all chlordanes (total chlordanes) [see Jackson et al. (1998) for constituents] and the sum of concentrations of 18 individual PCB congeners (total PCBs) [see Jackson et al. (1998) for constituents]. Bay mean values, determined using all measurements from all sites within each designated bay, were obtained geometrically for contaminants. Mean values of individual contaminants for each bay are given in Figures 1-8.

Data for 17 parasite/pathology groups were used for data analysis: rare parasites, prokaryotic inclusions, Haplosporidium nelsoni, Perkinsus marinus, gill ciliates, gut ciliates, body, mantle, and gill gregarines, nematodes, trematode sporocysts, trematode metacercariae, cestodes, major pathologies, tissue pathologies, ceroid bodies, and digestive gland atrophy. The sum of the counts of the rare parasites was obtained by excluding the common taxa (e.g. gregarines, ciliates, nematodes, cestodes and prokaryotic inclusions). The category of total prokaryotes included prokaryotic inclusions of chlamydia-like organisms and rickettsia-like organisms. Pathologies were grouped into two categories, major and tissue. Major pathologies included neoplasms, unusual digestive tubules, and gonadal abnormalities. Tissue pathologies included focal and diffuse hemocytic infiltration and granulocytomas as described in Villalba et al. (1997).

Parasite assemblages vary significantly between mussels, oysters, and dreissenids. In addition, mussels and oysters are characterized by inherently different contaminant affinities, at least for a number of metals (Rainbow, 1997; O'Connor, 1998; Valette-Silver et al., 1999; O’Connor, 2002). For these reasons, no betweentaxon comparisons are presented.

The largest bivalves were chosen due to the larger tissue volume required for multiple chemical analyses and the increased likelihood of equilibrium between contaminant exposure and contaminant body burden (e.g., Lee et al., 1972; Roesijadi et al., 1984; Hinch and Green, 1989; Palmer et al., 1993; Abbe and Sanders, 1990). 
These bivalves, being older, can also be presumed to have an increased incidence of some parasites and pathologies (e.g., Anderson and Gordon, 1982; Anderson and crombie, 1984; Aguirre-Macedo and Kennedy, 1999; Curtis et al., 2000; WilsonOrmond et al., 2000). Animal size and age vary between habitats and with latitude, as does the relationship of size with age (e.g., Hofmann et al., 1994; Weinberg, 1999). Some parasites have extended life spans; others do not (Powell et al., 1999; Curtis et al., 2000; Poulin and Morand, 2000), but the life spans of most bivalve parasites are very poorly known. The degree to which variation in the relationship of host size and age, as well as parasite transmission rate and life span, among Mussel Watch sites affects parasite and contaminant body burden cannot be evaluated; however, the focus on the largest animals can be expected to enhance the likelihood of identifying a relationship between parasite and contaminant.

Analysis of parasite/pathology occurrence began with the computation of prevalence and infection intensity. Prevalence, the fraction of individuals with the parasite or pathology, was calculated as:

$$
\text { prevalence }=\frac{\text { number animals affected }}{\text { number animals analyzed }} \text {. }
$$

Infection intensity, the average number of occurrences of a parasite or pathology in the affected individuals only, was calculated as:

$$
\text { infection intensity }=\frac{\sum_{i=1}^{n} \text { number of occurrences of parasite or pathology }}{\text { number affected individuals }} .
$$

For conditions rated using semiquantitative scales, the scale rating replaced the number of occurrences in this calculation. If a parasite or condition did not occur in a bay, infection intensity was undefined for that bay. A value of zero was not assigned.

Correlations were common among parasites for both variables (Kim and Powell, 2006) and occurred commonly as well among the contaminants (see also Ringwood et al., 1999; Green et al., 1983, 1993). Accordingly, to evaluate the potential relationships between parasites/pathologies and contaminant body burden in sentinel bivalves, principal components analysis (PCA) was used to reduce the many correlated variables in each dataset down to a few orthogonal variables for further analysis. Accomplishing this requires data points for each variable in each of the 126 bays. Infection intensity, unfortunately, is not defined for some variables in 
some bays because prevalence was zero. A full set of values exists for prevalence, but this variable does not provide any information about infection intensity. To resolve this dilemma, we calculated weighted prevalence or mean abundance, a measure often used in the bivalve literature (e.g., Ford, 1988; Kim and Powell, 2004), that combines prevalence and infection intensity:

$$
\text { weighted prevalence }=\text { prevalence } \times \text { infection intensity } .
$$

Bay average prevalences and infection intensities are reported in Kim and Powell (in press).

Separate PCAs were conducted for each species using the weighted prevalence of 17 parasite/pathology categories and 24 contaminant categories. Each variable was standardized to $\bar{x}=0$ and $s^{2}=1$ prior to using them in the PCA. Factor scores for factors having eigenvalues above 1.0 obtained from the weighted prevalence and contaminant body burden datasets were compared by ANOVA. The suite of individual variables with factor loads exceeding 0.5 for each significant contaminant factor $\times$ weighted prevalence factor in ANOVA were then compared in a posteriori tests to resolve potential reasons for the significant relationships between factor scores.

The a posteriori comparisons were conducted in two ways. First, we tested the significance of correlations between variables with factor loading scores $\geq 0.5$ for factors identified as significantly related by ANOVA using Spearman's Rank correlation tests. We confirmed that such correlations did not occur by chance using binomial tests (Conover, 1980). Second, double-zero pairs could not be removed from the PCA because all variables were simultaneously analyzed. These doublezero pairs are ambiguous. In some cases, double zeros occur simply because the bay was beyond the range of both parasites. In other cases, they occur if no affected animals were found for either condition in an area where each could occur. For this analysis, double-zero pairs introduced a possible bias because some relationships elucidated by PCA and a posteriori tests might exist due to the coincidence of low or zero values. Relationships of substance should be characterized by the cooccurrence of two high values more frequently, for positive correlations, or less frequently, for negative correlations, than expected by chance. We defined a 'high' value as a value exceeding the $75^{t h}$ percentile of all values for a variable. So, the 
results of significant Spearman's Rank tests were examined further by tallying the number of observations for each biological and contaminant variable greater than the $75^{t h}$ percentile value of all observations of that variable. Then, the occurrence rate for cases where the two variables were simultaneously high was compared to that expected by chance using a binomial test.

\section{Results}

Parasites and pathologies were rarely observed in dreissenid mussels, likely due to their recent introduction into the U.S. (Kim and Powell, in press, 2006). Oysters from Puerto Rico and Hawaii were different species and these sites were not readily assigned to geographic regions. As a consequence, dreissenids were not further analyzed and oyster analyses were limited to the East and Gulf coasts where $C$. virginica was sampled.

\section{Principal Components Analysis}

PCAs were run separately for mytilids and oysters. Factor axes for parasites/pathologies were determined by substantively different groups of parasites/pathologies in mytilids and oysters (Table 1). Similarities are remarkably few, and this is in keeping with the divergent geographic trends among the parasitic fauna, observed in these two taxa (Kim and Powell, in press). In mytilids, Factor 1 (P1) contained the three gregarines (Table 1). Kim and Powell (in press) suggested that mantle and body gregarines might be the same species, but the evidence supports a separation between these two and most gregarines occurring in the gill [see also Sprague and Orr $(1952,1955)$ ]. The gregarines did not fall on the same factor axis in oysters. Factor 2 (P2) in mytilids was determined by the pathologies and trematode sporocysts. The rare parasites and prokaryotic inclusions determined Factor 3 (P3). Trematode metacercariae, digestive gland atrophy, and ceroid bodies determined Factor 4 (P4). Factor 5 (P5) was determined by the ciliates. Again, in oysters, as for the gregarines, the ciliates did not fall on the same axis as they did for the mytilids. For oysters, P1 was determined by gill gregarines and $P$. marinus. Prokaryotic inclusions and major pathologies determined P2. The remaining gregarines determined P3. P4 combined the tissue pathologies, ceroid bodies, and cestodes. Trematode sporocysts and gut ciliates fell on P5. Kim and 
Powell (2006, in press) discuss the geographic relationships of these parasites and pathologies in more detail.

The contaminant PCAs were much more consistent between the two taxa (Table 1). Each contained a PAH-dominated factor (C1), a pesticide-dominated factor (C3), and three metal-dominated factors. $\mathrm{Ag}$ and $\mathrm{Zn}$ fell on the same PCA axis in both PCAs. Mirex and $\mathrm{Pb}$ fell on the same PCA axis in both PCAs. $\mathrm{Cu}$ and $\mathrm{Hg}$ did likewise, as did $\mathrm{Zn}, \mathrm{Ni}$, and $\mathrm{Cd}$. Total chlordanes, for both species, contributed significant influence to both the $\mathrm{PAH}$-dominated and the pesticide-dominated axis. Finally, the PAH-dominated axis was defined by 6 contaminants common to both taxa and the pesticide-dominated axis was defined by 4 contaminants common to both taxa (Table 1 ). For the mytilids, $\mathrm{Cu}, \mathrm{Hg}$ and $\mathrm{Pb}$ combined with two pesticides on Factor axis $2(\mathrm{C} 2) . \mathrm{Cd}, \mathrm{Cr}, \mathrm{Fe}, \mathrm{Ni}$, and $\mathrm{Zn}$ loaded on Factor axis 4 (C4). Ag, As and $\mathrm{Zn}$ defined Factor axis 5 (C5). In oysters, $\mathrm{Ag}, \mathrm{Cd}, \mathrm{Cu}, \mathrm{Ni}$ and $\mathrm{Zn}$ loaded on $\mathrm{C} 2$; $\mathrm{Cr}, \mathrm{Cu}$ and $\mathrm{Hg}$ on $\mathrm{C} 4$; and $\mathrm{Fe}, \mathrm{Pb}$, and $\mathrm{Se}$, with mirex, on C5. Common to $\mathrm{C} 1$ in both PCAs were phenanthrene, fluoranthene, pyrene, chrysene, total chlordanes, and total PAHs. Total PCBs contributed to this axis in oysters. Common to C3 were total DDTs, aldrin, dieldrin, and total chlordanes. Lindane and total PCBs contributed to this axis in oysters. Presley et al. (2004) also observed correlations between $\mathrm{Cu}$ and $\mathrm{Zn}$ in oysters from Gulf of Mexico Mussel Watch sites, in agreement with their co-occurrence on Factor axis 2. The tendency for the metals to be distributed independently of the organics also conforms to earlier analyses of Mussel Watch data (Wilson et al., 1992; Kim et al., 2001). Interestingly, one common contaminant, naphthalene, did not fall on any of the five primary PCA axes in either taxon suggesting an inherent difference in the distribution of this contaminant in comparison to the others.

Significant relationships between contaminants and parasites/pathologies were examined by ANOVAs comparing PCA factors. A total of 25 tests, 5 parasite/pathology factors $\times 5$ contaminant factors, were performed for each taxon. Six of these tests were significant for mytilids (Table 2), considerably more than anticipated by chance at the least significant significance level obtained (Table 2) (tested probability $p$, significance level $P ; p=0.015, P<0.0001$ ). Five were significant for oysters. Once again, this number is considerably more than anticipated 


\section{ACCEPTED MANUSCRIPT}

Final xDraft - September 11, $2007 \quad 15$

by chance $(p=0.029, P<0.0001)$. We also differentiated the oysters on the East and Gulf coasts and the mytilids on the East and West coasts. For the oysters, at this geographic scale, 5 tests were significant in the Gulf and 2 on the East coast. The number of significant comparisons for Gulf oysters exceeded that expected by chance $(p=0.026, P<0.0001)$. The number on the East coast did not. Thus, significant results overall were principally a function of the Gulf of Mexico portion of the oyster dataset. For the mytilids, 3 comparisons were significant on the East coast. This exceeded the number anticipated by chance $(p=0.033, P<0.01)$. The frequency on the West coast, however, did not exceed the frequency expected by chance.

The PAH-dominated factor, $\mathrm{C} 1$, generated significant comparisons with parasite/pathology factors in both oysters and mussels. For oysters, the significant comparison was with $\mathrm{P} 4$ (tissue pathologies, cestodes, ceroid bodies). Interestingly, for mussels, the significant factor, P3, contained a very different parasite complement, rare parasites and prokaryotic inclusions. Thus, PAHs were associated with a number of pathologies and tissue components, ceroid bodies, thought to have detoxification abilities (Zaroogian et al., 1989, 1993) in oysters, but not in mussels. The pesticide-dominated factor (C3) had significant comparisons also with P4 in oysters, but with no mytilid parasite/pathology factors.

Among the metals, a mytilid factor containing gill gregarines (P1) was significantly related to a factor containing the metals $\mathrm{Ag}$ and $\mathrm{Zn}$ (C5). $\mathrm{Cu}$ and $\mathrm{Hg}$ fell on the same axis on both mytilid and oyster PCAs. In mytilids, $\mathrm{C} 2$ that included $\mathrm{Cu}, \mathrm{Hg}, \mathrm{Pb}$, and mirex demonstrated significant comparisons with $\mathrm{P} 1$ (gregarines) and P2 (pathologies and trematode sporocysts). The factor containing $\mathrm{Cu}$ and $\mathrm{Hg}$ in oysters (C4), however, showed no significant comparisons, but $\mathrm{C} 5$ that contained $\mathrm{Pb}$ and mirex (plus Se, Fe) showed significance with $\mathrm{P} 1$, also a gregarine containing factor, and P2, a pathology containing factor (with prokaryotic inclusions). Ni, Zn, and $\mathrm{Cd}$ fell on the same PCA axis in both mytilid and oyster PCAs. For oysters, this axis (C2) was significantly related to $\mathrm{P} 4$ (tissue pathologies, ceroid bodies, and cestodes). For mytilids, C4 was significantly related to P2 (pathologies) and P4 (trematode metacercariae, ceroid bodies and digestive gland atrophy). 


\section{A Posteriori Spearman's Correlations}

A posteriori tests were confined to cases where significant ANOVA comparisons occurred more frequently than expected by chance. For the mytilids, six significant relationships existed between contaminant and parasite/pathology PCA factors out of a possible 25 (Table 2), an incidence that far exceeds the incidence anticipated by chance. From these, 43 significant contaminant-parasite/pathology a posteriori correlations were obtained out of a possible 81. Among the 43 pairs with significant relationships, 30 achieved significant levels at $\alpha \leq 0.01$ (Table 3 ). Thirty of 81 far exceeds the incidence expected by chance $(p=0.01, P<0.0001)$. Forty-three of 81 reached significance at $\alpha \leq 0.05$, a frequency also exceeding chance $(P<0.0001)$. Of these 43, 26 were negative, a frequency not exceeding chance. Thus, negative and positive correlations were about equally likely.

The majority of significant correlations in the mytilids involved metals, 33 of 43 (Table 3). Correlation tests with metals involved $70 \%$ of the 81 possible tests. Both significance tests with metals and with organics occurred more frequently than expected by chance (metals: 33 of 57, $p=0.05, P<0.0001$; organics: 10 of 24, $p=0.05, P<0.0001)$. Taking into consideration the differential in the number of tests, 57 versus 24, significant differences with metals occurred significantly more frequently than with organics $(P<0.0001)$. Finally, positive correlations occurred in 7 of 10 significant tests for the organics, a frequency no different than chance. For the metals, the ratio was 10 of 33, a frequency much lower than expected by chance $(P<0.02)$; hence significant correlations with metals were significantly more likely to be negative. A substantial number of the significant correlations for mytilids involved the gregarines; however, gregarines were absent from East-coast mytilids and this absence might have reinforced an East coast-West coast difference in metal body burden yielding the observed significant a posteriori tests. Removing the suspect gregarines does not materially change conclusions deduced from this battery of tests, with one exception. The frequency of positive versus negative correlations no longer differs from that expected by chance.

Excluding the suspect gregarines, the majority of the correlations with metals, whether positive or negative, involved major pathologies, tissue pathologies (mostly granulocytomas), and trematode sporocysts and metacercariae. Single-celled para- 
sites offered no significant correlations with metals in mytilids. Among organic contaminants, mirex was positively associated with tissue pathologies. Fluoranthene, pyrene, and total PAHs showed weak positive relationships with rare parasites. Total PCBs were positively correlated with major/tissue pathologies and trematode sporocysts. Excluding the gregarines, all correlations with organics were positive, higher weighted prevalence being associated with higher contaminant body burden. Among the metals, $\mathrm{Cd}, \mathrm{Cr}, \mathrm{Fe}, \mathrm{Ni}$, and $\mathrm{Zn}$ exclusively demonstrated significant negative correlations, whereas $\mathrm{Cu}, \mathrm{Hg}$, and $\mathrm{Pb}$ were exclusively involved in significant positive correlations. Such an outcome would not be expected by chance.

Limiting the analysis to East-coast $M$. edulis produced significant relationships in ANOVA more frequently than expected by chance. From these, nine significant contaminant-parasite/pathology pairs were identified out of 33 possible, a frequency that is greater than expected by chance $(p=0.05, P<0.0001)$. About one-third were positive correlations. With one exception, all involved digestive gland atrophy, ceroid bodies, and trematode metacercariae (Table 4). All of the latter two were negative. All for digestive gland atrophy were positive. Such an outcome would not be expected by chance. The single significant ANOVA for West-coast mytilids may have occurred by chance; nevertheless, we include the a posteriori tests in Table 4 because of their unusual nature; all involve PAHs and major pathologies, and all are positive.

The ANOVAs for oysters yielded five significant relationships between contaminant and parasite/pathology factors (Table 5), an incidence not anticipated by chance. A posteriori Spearman's Rank correlations identified 19 significant individual contaminant-parasite/pathology pairs out of 70 possible. Ten achieved significance levels exceeding $\alpha=0.01$ (Table 5 ). Ten of 70 possible far exceeds the incidence expected by chance $(p=0.01, P<0.0001)$, as does 19 of 70 at $p=0.05$. Of these, 8 were positive, a frequency possibly obtained by chance. Negative and positive correlations were equally likely.

Among the 19 correlations in oysters, nine significant comparisons occurred with the metals, and ten with organic contaminants (Table 5). Correlation tests with metals involved $38.6 \%$ of the 70 possible tests. Both significance tests with metals and with organics occurred more frequently than expected by chance (metals: 
9 of 27, $p=0.05, P<0.0001$; organics: 10 of 43, $p=0.05, P<0.0001)$. Taking into consideration the differential in the number of tests, 27 versus 43 , significant differences with metals occurred less frequently than with organics $(P<0.05)$. Finally positive correlations occurred in 3 of 10 significant tests for the organics, a frequency no different than chance. For the metals, the ratio was 5 of 9 , a frequency also no different than expected by chance.

All negative correlations in oysters were with metals and pesticides or PCBs (Table 5). The vast majority of these significant results involved cestodes and tissue pathologies. All positive correlations were with metals and PAHs. Interestingly, these covered a range of parasite and pathology types. Tissue pathologies were more frequently significant with metals than with pesticides, whether the correlation was positive or negative.

Overall ANOVAs were driven principally by the Gulf oyster dataset. Not surprisingly, restricting a posteriori tests to the Gulf dataset yielded essentially the same results, with one important exception. Body and mantle gregarines were negatively correlated with a variety of pesticides (Table 6).

\section{Re-examination of Spearman's Rank Correlations}

Correlations obtained from the Spearman's Rank correlation tests may occur because of frequent co-occurrences of low parasite/pathology-low contaminant values. The most important correlations should be those produced by a coincidence of high parasite/pathology and high contaminant values exceeding (positive) or falling below (negative) the number expected by chance. We re-examined each significant correlation focusing on the values that exceeded the $75^{\text {th }}$ percentile value of all observations.

Restricting significant correlations to those meeting this more stringent criterion decreased the number of significant results for the mytilids from 43 to 22 (Table 3). The overall distribution of significant results was not much changed, however. Some correlations with gregarines were lost, but some remained. The frequency of significant results with major pathologies and tissue pathologies was much reduced, but these two biological variables continued to manifest important relationships with contaminants. No pesticide or $\mathrm{PAH}$ relationship survived this 
analysis, however, with one exception, mirex. Only metals and PCBs remained. Separate analyses for East- and West-coast mytilids also remained qualitatively the same, although the more stringent criterion retained only $57 \%$ of the original Spearman's Rank correlations.

The more stringent $75^{t h}$ percentile requirement retained only five of the 19 significant Spearman's Rank correlations for oysters. These involved metals and pesticides exclusively; no PAH correlation was retained. These dominantly involved cestodes; no relationship with tissue pathologies or ceroid bodies was retained. Restricting the analysis to the Gulf of Mexico oysters reduced the 20 significant Spearman's Rank correlations to three, again involving exclusively pesticides and metals; no PAH correlation was retained.

\section{Discussion}

\section{Approach}

McDowell et al. (1999) argued that establishing a causal relation between parasites/pathologies observed in bivalve populations and a specific contaminant is inherently difficult, as different types of contaminants simultaneously occur as mixtures, as organisms are exposed to these complex environmental mixtures, not individual contaminants, and as synergistic or antagonistic effects of several classes of contaminants may occur. We add that this same complication exists with parasites and pathologies: most animals are parasitized by multiple taxa (Kim and Powell, 2006); some taxa promote certain pathologies (Kim and Powell, 2004; Kim and Powell, in press); and the infection process is inherently and substantially influenced by processes external to prospective hosts (e.g., Mollison and Levin, 1995; Ford and Tripp, 1996). Bearing these points in mind, we resolve possible relationships between biological and contaminant variables in this study by first utilizing PCA to identify relationships between multiple contaminants and multiple parasites/pathologies (Table 2); we then investigate these relationships in more detail. Because the co-occurrence of low values of parasite/pathology and contaminant might occur for many reasons, a stepwise progression was used to remove from consideration parasite/pathology-contaminant pairs that might originate strictly from frequent co-occurrences of low parasite/pathology-low contaminant pairs. The final 
stringent culling of statistical results focused solely on the frequency of co-occurrence of high values of parasite/pathology and contaminant (Tables 3-6).

Positive associations surviving the final cull are cases in which a high contaminant and a high parasite/pathology value co-occurred more frequently than expected by chance. A diversity of possibilities exists to explain these findings: contaminant stresses may reduce host resistance thus increasing susceptibility to parasitism; some parasites may preferentially accumulate certain contaminants in their tissues to a greater extent than their hosts; environmental influences may simultaneously increase contaminant availability and the chance of infection; some parasites may increase host contaminant body burden by modulating accumulation rate; and/or some parasites, through their influence on reproduction or physiology, may decrease depuration or detoxification rate. Negative relationships surviving the final cull are cases in which a high contaminant value and a high parasite/pathology value co-occurred less frequently than expected by chance. A diversity of possibilities exists to explain these findings as well: some contaminants may negatively impact the parasite directly; environmental influences may increase contaminant availability and simultaneously reduce the chance of infection; and/or lower tissue affinity in the parasite may lower apparent host body burden at high infection intensity.

One caveat applies to the comparisons that include data from multiple coasts. Parasites/pathologies vary between coasts; the most obvious case being the absence of gregarines in mytilids on the East coast (Kim and Powell, in press). Some relationships might simply be due to the coincidence of changes in parasite availability and transmission process and the availability of contaminants in the watershed. As one cannot, in most cases, discount a more causative interaction, we include these larger-scale analyses. However, emphasis is placed on within-coast comparisons.

Finally, we note that large-scale climate processes acting through variations in temperature and rainfall (salinity) may play an important role in establishing many of the observed parasite/pathology distributional patterns over broad geographic regions (Kim and Powell, in press). Because the process of contaminant accumulation is normally temperature-dependent (Reid et al., 1997; Kennedy and Walsh, 1997) and because contaminant source loadings and local concentrations are 
affected by rainfall and freshwater inflow (Wilson et al., 1992; Kim et al., 2001), trends in the physiology of contaminant accumulation could be similar to trends in the occurrence of parasitism (e.g., Wenzloff et al., 1979) without any inherent interaction between the two. Accordingly, we focus on distinctive patterns that, by their uniqueness, seem unlikely to be explained in so simple a fashion.

\section{Trends in Correlations: The Contaminant Perspective}

Different contaminants seldom occur in isolation in the environment but are present as mixtures with other organic and inorganic contaminants (Moore et al., 1984; Hagopian-Schlekat et al., 2001). Murphy (1980) suggested that identified biological responses to chemical stress are unlikely to have been caused by a single contaminant (see also Ringwood et al., 1999). Synergies are commonly reported from controlled multi-contaminant experiments (Hagopian-Schlekat et al., 2001; Chu and Chow, 2002). PCA analyses of 1995-1998 Mussel Watch data resolved five groups of contaminants (Table 1). In both mussels and oysters, these five included one dominated by PAHs, one dominated by pesticides, and three dominated by metals. Most of the common contaminants fell on one or the five primary PCA axes. The most significant exception was naphthalene that, among the five most common PAHs, did not load on any of the primary contaminant PCA axes. Metals produced a much more complex picture of spatial trends in body burden than did either the pesticides or PAHs. Furthermore, certain similarities existed in the metal groupings between the two taxa. $\mathrm{Ag}$ and $\mathrm{Zn}$ fell on the same PCA axis in both PCAs. Mirex and $\mathrm{Pb}$ fell on the same PCA axis in both PCAs. $\mathrm{Cu}$ and $\mathrm{Hg}$ did likewise, as did $\mathrm{Zn}, \mathrm{Ni}$, and $\mathrm{Cd}$.

Contrasted to the relative simplicity of contaminant trends was the diversity exposed by the PCAs for parasites and pathologies. Very few similarities between the sentinel bivalve taxa existed. This was due in part to the different taxa parasitizing these bivalves. Cestodes and nematodes were present only in oysters. Trematode metacercariae were vastly more abundant in mussels, as were major pathologies. Further examples abound. Thus, the relationship between parasites/pathologies and contaminants can be expected to be different between taxa despite the similarity in contaminant pattern. 
Despite the complexity of the biology, significant contaminant versus parasite/pathology differences occurred much more frequently than expected by chance when the two suites of PCA factors were compared. Nevertheless, when the contributors to the PCA factors were compared individually, not all individual variable pairs in each significant factor showed correlations in a posteriori Spearman's Rank tests (Tables 3-6), even though the overall comparison between factor scores reached high levels of significance (often $P \leq 0.001$ ). In some cases, none of them did! Thus, the analysis suggests that combined effects of many contaminants and parasites may be important, leading to complex biological-contaminant interactions with synergiies both of biological and chemical origin.

Overall, correlations between parasites/pathologies and contaminants were more frequent with metals, frequent with pesticides, and less frequent with PAHs in mussels. In oysters, correlations with pesticides and metals were about equally frequent, but correlations with PAHs were still rare. Most associations may be due to inherently different contaminant loads in species and coasts, but even at the lowest spatial scale (i.e. East-coast M. edulis, Gulf-coast oysters), the metals (and pesticides in oysters) produced most of the significant correlations. Inasmuch as metals contribute a large portion of the analytes examined in this study, this outcome might be anticipated. However, the frequency accrues not from this source, but from the diversity of metal groups in the PCA, of which three were identified in each taxon, and the common occurrence of significant Spearman's Rank correlations with individual metals contributing to these metal-dominated PCA factors. Negative and positive correlations occurred with about the same frequency, both in oysters and in mytilids, once the suspect gregarines were excluded for the mytilids. For metals, important positive associations were recognized between $\mathrm{Pb}, \mathrm{Hg}$, and $\mathrm{Cu}$ and trematode sporocysts in mytilids. Negative correlations occurred between a number of metals and trematode metacercariae, as well as both types of pathologies in mytilids. For the oysters, positive correlations involved principally $\mathrm{Pb}$, with $\mathrm{Cd}$ and $\mathrm{Ni}$ contributing most of the negative ones. The positive relationship between major pathologies and $\mathrm{Pb}$, and the negative relationship between tissue pathologies and both $\mathrm{Cd}$ and $\mathrm{Ni}$ occurred in both mytilid and oyster datasets 
Correlations with pesticides and PCBs, though less common than with the metals in mussels, were relatively frequent in both taxa and more common in oysters than in mytilids. The majority of associations related to pesticides were negative ones. In mytilids, positive correlations were limited to the PCBs. None existed in the oysters. Negative correlations occurred with mirex for the mytilids and with a variety of pesticides and the PCBs in oysters. A negative correlation between cestodes from East-coast oysters with total hexachlorocyclohexane ( $\mathrm{HCH})$, a synthetic pesticide that does not occur naturally in the environment, was identified by Kim et al. (1998). In this study, all potential relationships of cestodes in oysters with manufactured organic chemicals (i.e. total DDT, aldrin, dieldrin, lindane, and total PCBs) were negative (Tables 5 and 6), suggesting that locations with higher infection intensity of cestodes tended to co-occur with lower body burden of these contaminants.

PAHs rarely showed significant relationships with parasites/pathologies in this study. Powell et al. (1999) reported similarly that parasites observed in petroleum seep mussels were nevertheless rarely significantly associated with PAH body burdens.

Lipophilic organic contaminants (e.g., PAHs) are easily depurated by spawning as they are enriched in gametic tissue (Jovanovich and Marion, 1987; Ellis et al., 1993). Ellis et al. (1993) noted that pesticides are concentrated in eggs but not in sperm, so that depuration through spawning would influence only a portion of the bivalve population. Metals are less influenced by spawning (e.g., Cunningham and Tripp, 1975; Greig et al., 1975) than organics, and thus metals tend to stay in the tissues. This may be the reason why the majority of associations identified in this study came from metals, as they are present in higher concentrations over longer periods, and so can more strongly influence the biology of both host and parasite. Pesticides fell in between as anticipated by their apparently more limited depuration through spawning (Ellis et al., 1993). PAHs, most easily depurated through spawning, were rarely characterized by significant correlations.

The inverse ranking of spawning as a depuration mechanism and the frequency of significant correlation are gripping and argue for a much closer look at this key linkage in explaining spatial trends in monitoring studies. The same ranking would 
promote a greater and longer-term interaction between parasites/pathologies and metals than PAHs, as is observed. The infrequency of significant effects between Se and parasites/pathologies is potentially noteworthy in this regard as this metal may be lost through spawning (Baldwin and Maher, 1997). However, one cannot exclude the differential in effects levels that tend to be much lower for pesticides than PAHs (Long et al., 1995) as contributing to the intermediary nature of the pesticides. PAHs may simply be less toxic and therefore less influential in affecting the occurrence of parasites/pathologies.

\section{Trends in Correlations: The Biological Perspective}

Of the 23 significant correlations involving parasites, after discounting the gregarine relationships in mytilids and the rare parasite group that combines a variety of taxa, only 3 involve single-celled eukaryotes or prokaryotes (Tables 3 and $5)$. This is significantly fewer than expected by chance $(p=0.01, P<0.0001)$. The remaining involve multi-cellular eukaryotes and nearly all of them either cestodes, trematode sporocysts, or trematode metacercariae. Some of the frequently significant relationships observed with tissue pathologies, particularly the hemocytic infiltration in oysters, probably accrue also in this way, as these worms, with the exception of the trematode sporocysts, are often observed to locally increase hemocyte concentration in bivalves (Cheng, 1966; Cheng and Rifkin, 1968; Kim and Powell, 2004). The few correlations for single-celled parasites all involve proliferating protozoa ( $P$. marinus) or protozoa reaching high body burdens through transmission (the gregarines). With two exceptions, the parasites involved in significant correlations with contaminants are not known to do great damage to the host, the exception being $P$. marinus and the trematode sporocysts. The non-random distribution of significant correlations and the tendency for the larger or more numerous parasites to be involved argue that unequal sequestration of contaminants between host and parasite tissue is a potential mediator. Negative and positive correlations occur with about equal frequency, suggesting that, if present, the principal differential may be either a lower or higher body burden in parasitic tissue. This expectation differs from that expected from Sures et al. (1999).

One interesting tendency was for correlations with pathologies to be principally with the mytilids. The few in oysters always co-occurred with cestodes and are 


\section{ACCEPTED MANUSCRIPT}

Final xDraft - September 11, $2007 \quad 25$

likely derived from hemocytic infiltration near cestode cysts. With the mytilids, pathologies, major and tissue (mostly granulocytomas in this case), were common and correlations widespread among the metal, pesticide, and PAH contaminants.

A posteriori correlations did not occur more frequently than expected by chance in East-coast oysters and West-coast mussels. The ready explanation of multiple taxa on the West coast compromising the analysis is belied by the case of oysters on the East coast. These two coastline stretches are unique in having the widest temperature range. Each contains significant provincial boundaries (Hall, 1964; Valentine, 1966). The influence of the large temperature range on parasite distributional pattern potentially minimizes the possibility that correlations with contaminants can be identified. Shorter coastline stretches bounded by provincial boundaries might be investigated advantageously.

\section{Noteworthy Specific Relationships}

Couch (1985) found that industrialized sites had a tendency to show a higher frequency of oysters parasitized or diseased, suggesting that pollution stress can be a major contributing factor in the occurrence of disease in animals from degraded habitats. Villalba et al. (1997) noticed a higher parasite load in mussels from areas of higher levels of pollution in Spain. Other studies have suggested possible relationships between certain parasites or disease conditions in marine bivalves and pollution by identifying chemical contaminants as causative factors for detrimental biological effects. Kraak and Davids (1991) found that organisms weakened by parasitism contained higher levels of some metals, for example. From all of these studies, one might anticipate that positive correlations between parasite body burden and contaminant body burden would be the norm. Nevertheless, in this study, positive correlations were no more common than negative ones. A strong tendency existed for the correlations to be of equivalent trend in both mytilid and oyster taxa. Thus, correlations with $\mathrm{Cd}$ and $\mathrm{Ni}$ were negative in both taxa. Positive correlations occurred in both taxa for $\mathrm{Pb}$.

Exposure to contaminants can increase the bivalve host's susceptibility to disease and thus enhance disease infections (Chu and Hale, 1994; Chu, 1996; McDowell et al., 1999). This study identified two positive associations with 
P. marinus, for $\mathrm{Pb}$ and Se. No correlations were negative. Guth et al. (1977) showed that snails parasitized by trematodes were more susceptible to $\mathrm{Zn}$ than unparasitized snails. In contrast, Zn entered into a number of significant correlations with trematodes in this study; all were negative. From a previous Mussel Watch Program by the EPA, Yevich and Barszcz (1983) reported correlations between locations with high parasitism and locations high in PCBs. Kim et al. (1998) also reported that trematode sporocysts in $M$. edulis were positively correlated with body burdens of total PCBs. Evidence to support these observations from this study includes the fact that total PCB levels in mytilids were positively associated with infections by trematode sporocysts.

Barszcz et al. (1978) reported that oysters exposed to crude oils had an increased intensity of infection, showing that contaminant stress plays a role in increased parasitism. Neff et al. (1987) also noted a relationship between parasitism and oil exposure. In this study, relationships with PAHs were rare; the only noteworthy exception was the relationships elucidated in West-coast mussels between a variety of PAHs and pathologies. Barszcz et al. (1978) also noted that bivalves with reduced resistance to infection due to higher contaminant body burdens are more likely to become hosts to opportunistic parasites and that contaminant exposure may help parasites already present in hosts to proliferate. Laird (1961) forwarded a similar hypothesis. Our analysis of rare parasites, anticipated to follow this trend, yielded few significant correlations, though all were positive.

Lowe and Moore (1979) showed that areas of high pollution have a high incidence of granulocytomas characterized by an inflammatory cellular condition in mytilid mussels from England and Wales. Confirmatory data come from Villalba et al. (1997), Svärdh (1999), and Svärdh and Johannesson (2002). In this study, tissue pathologies, principally granulocytomas, in mytilids were more common and abundant in East-coast $M$. edulis, especially from Massachusetts to Delaware, than in West-coast mytilids. Contaminant concentrations are also high in these animals, on the average (O'Connor and Ehler, 1991; O'Connor, 2002). With the exception of $\mathrm{Cd}$, highly significant correlations between tissue pathologies and contaminants were positive in mytilids. This included metals $(\mathrm{Pb}, \mathrm{Hg})$ and $\mathrm{PCBs}$. 
Ceroid bodies or brown cells are thought to have detoxification abilities (Zaroogian et al., 1989, 1993). Cd, Ni, and certain PAHs are implicated (Zaroogian et al., 1993). Interestingly, correlations with ceroid bodies were always positive, with one exception in mytilids. These positive correlations occurred solely in oysters and involved $\mathrm{Zn}$ and certain PAHs. Digestive gland atrophy has been shown to be responsive to environmental stress in mytilids and other bivalves (Widdows et al., 1982; Axiak et al., 1988; Hinton et al., 1992; Da Ros et al., 1998), particularly metals. In this study, all significant correlations were observed in mytilids and all were positive. Their absence in oysters is possibly explained by the relationship of this tissue condition and nutritional status in oysters (Winstead, 1995; but see Gold-Bouchot et al., 1995).

\section{Conclusions}

Estuarine and coastal marine waters receive many kinds of organic and inorganic contaminants that potentially have adverse effects on biota living in these habitats and possibly on humans who consume them. Sessile bivalve mollusks can be used effectively as bioindicators to monitor the status and trends of coastal water quality. Whether parasites/pathologies can be used as biomarkers is still unclear, but some observations are noteworthy. The distribution of parasites/pathologies within taxa and along coasts is sufficiently complex that a universal relationship with contaminants is an unachievable goal. Relationships may be present at smaller spatial scales, however, and within taxon.

Several studies have suggested parasites as potential biomarkers of pollution. Some focus on particular parasite types (Thulin, 1989); others on broader indicies of parasite species richness and diversity (Schmidt et al., 2003). In this study, the gregarines, the most common parasites in oysters exclusive of the disease-causing $P$. marinus, were responsible for a large fraction of the relationships with contaminants found in Gulf-coast oysters. These were exclusively inversely associated with pesticides, suggesting an underlying relationship. Cestodes, another common parasite, were exclusively negatively associated with metals and pesticides. The possibility that some parasites such as the gregarines and cestodes in oysters might be useful biomarkers is indicated by this study. That the common parasites are most important is particularly critical to establish biomarkers of general useful- 
ness. The trend for common parasites to display correlations with contaminants is also present in mussels, where trematode sporocysts and metacercariae contributed most significant correlations, and nearly exclusively with metals. In contrast to the promise shown by the metals, and by pesticides in oysters, PAH biomarkers are unlikely to be found among the parasites. Correlations with PAHs were remarkably rare. The ease of depuration of PAHs through spawning offers a likely explanation.

Interactions between different types of contaminants present as mixtures in estuarine and coastal waters must be common. Not all individual parasite/pathologycontaminant pairs in each significant PCA factor pair showed significant correlations, although the overall comparison between PCA factors loaded by multiple biological and contaminant variables reached high levels of significance. Thus, this study re-enforces the contention that combined effects of many contaminants and parasites may be important, and emphasizes the complexity of parasite-contaminant interactions, considering the other biological and environmental variables involved. For this reason, parasites are unlikely to be responsive to single contaminants, but they are likely to respond to classes of contaminants and the number of such classes is relatively few; five in the case of mytilids and oysters in this study. Thus, these results also support continued evaluation of parasite/contaminant interactions.

As parasitism can influence the sensitivity of host bivalves to contaminant exposure and affect the spawning of animals as a means of contaminant loss, and as parasites may respond directly to contaminants and influence host body burden directly, the study of parasites and pathologies should be included in biomonitoring and toxicity studies as is now the case in the Mussel Watch Program. The supposition that increased parasitism and increased contaminant body burden should co-occur was not uniformly supported, however. A surprising number of significant correlations between contaminants and parasites/pathologies, about half of all correlations, were negative, suggesting that some contaminants may negatively affect parasites more than their hosts. The importance of parasites in community diversity is attracting increasing attention (Hawkins, 1990; Sousa, 1991; Thomas et al., 1997; Rohde, 2002). As parasites are potentially more sensitive than hosts to environmental disturbance, the possibility that contaminants may reduce the abundance of some parasites is deserving of attention. More multidisciplinary 


\section{ACCEPTED MANUSCRIPT}

Final xDraft - September 11, $2007 \quad 29$

studies on the interactive biological influences of environmental stressors (e.g., multiple contaminants) on marine organisms, both hosts and parasites, in estuaries and coastal waters are required to further elucidate these relationships.

\section{Acknowledgments}

We thank the Status and Trends field and laboratory teams at Texas A\&M University and TDI-Brooks International who collected the animals for histopathological analysis. The Status and Trends program is supported through contracts with the U.S. Department of Commerce, National Oceanic and Atmospheric Administration, National Ocean Service.

\section{References}

Abbe, G. R., \& J. G. Sanders. (1990). Pathways of silver uptake and accumulation by the American oyster (Crassostrea virginica) in Chesapeake Bay. Estuarine, Coastal and Shelf Science, 31, 113-123.

Aguirre-Macedo, M. L., \& C. R. Kennedy. (1999). Diversity of metazoan parasites of the introduced oyster species Crassostrea gigas in the Exe Estuary. Journal of the Marine Biological Associatin of the United Kingdom, 79, 57-63.

Anderson, R. M., \& J. Crombie. (1984). Experimental studies of age-prevalence curves for Schistosoma mansoni infections in populations of Biomphalaria glabrata. Parasitology, 89, 79-104.

Anderson, R. M., \& D. M. Gordon. (1982). Processes influencing the distribution of parasite numbers within host populations with special emphasis on parasiteinduced host mortalities. Parasitology, 85, 373-398.

Axiak, V., J. J. George, \& M. N. Moore. (1988). Petroleum hydrocarbons in the marine bivalve Venus verrucosa: Accumulation and cellular responses. Marine Biology (Berlin), 97, 225-230.

Baldwin, S., \& W. Maher. (1997). Spatial and temporal variation of selenium concentration in five species of intertidal molluses from Jervis Bay, Australia. Marine Environmental Research, 44, 243-262. 


\section{ACCEPTED MANUSCRIPT}

Final xDraft - September 11, 2007 30

Barszcz, C. A., P. P. Yevich, L. R. Brown, J. D. Yarbrough, \& C. D. Minchew. (1978). Chronic effects of three crude oils on oysters suspended in estuarine ponds. Journal of Environmental Pathology and Toxicology, 1, 879-895.

Boyce, N. P., \& S. B. Yamada. (1977). Effects of a parasite, Eubothrium salvelini (Cestoda: Pseudophyllidea), on the resistance of juvenile sockeye salmon, Oncorhynchus nerka, to zinc. Journal of the Fisheries Research Board of Canada, 34, 706-709.

Boyden, C. R., \& D. J. H. Phillips. (1981). Seasonal variation and inherent variability of trace elements in oysters and their implications for indicator studies. Marine Ecology Progress Series, 5, 29-40.

Burreson, E. M., \& L. M. Ragone Calvo. (1996). Epizootiology of Perkinsus marinus disease of oysters in Chesapeake Bay, with emphasis on data since 1985. Journal of Shellfish Research, 15, 17-34.

Cantillo, A. Y. (1992). NOAA National Status and Trends Program quality assurance program. In Fourth annual ecological quality assurance workshop. EPA/600/R-92/097, 87-92.

Cheng, T. C. (1966). The coracidium of the cestode Tylocephalum and the migration and fate of this parasite in the American oyster, Crassostrea virginica. Transactions of the American Microscopy Society, 85, 246-255.

Cheng, T. C., \& E. Rifkin. (1968). The occurrence and resorption of Tylocephalum metacestodes in the clam Tapes semidecussata. Journal of Invertebrate Pathology, $10,65-69$.

Chu, F-L. E. (1996). Laboratory investigations of susceptibility, infectivity and transmission of Perkinsus marinus in oysters. Journal of Shellfish Research, 15, $57-66$.

Chu, F-L. E., \& R. C. Hale. (1994). Relationship between pollution and susceptibility to infectious disease in the Eastern oyster, Crassostrea virginica. Marine Environmental Research, 38, 243-256.

Chu, K. W., \& K. L. Chow. (2002). Synergistic toxicity of multiple heavy metals 
Final xDraft - September 11, $2007 \quad 31$

is revealed by a biological assay using a nematode and its transgenic derivative. Aquatic Toxicology, 61, 53-64.

Conover, W. J. (1980). Practical nonparametric statistics. New York: John Wiley $\&$ Sons.

Couch, J. A. (1985). Prospective study of infectious and noninfectious diseases in oysters and fishes in three Gulf of Mexico estuaries. Diseases of Aquatic Organisms, 1, 59-82.

Couch, J. A., L. A. Courtney, J. T. Winstead, \& S. S. Foss. (1979). The American oyster (Crassostrea virginica) as an indicator of carcinogens in the aquatic environment. In: Animals as monitors of environmental pollutants. (pp. 65-84) Washington, DC: National Academy of Sciences.

Craig, A., E. N. Powell, R. R. Fay, \& J. M. Brooks. (1989). Distribution of Perkinsus marinus in Gulf Coast oyster populations. Estuaries, 12, 82-91.

Cunningham, P. A., \& M. R. Tripp. (1975). Factors affecting the accumulation and removal of mercury from tissues of the American oyster Crassostrea virginica. Marine Biology (Berlin), 31, 311-319.

Curtis, L. A., J. L. Kinley, \& N. L. Tanner. (2000). Longevity of oversized individuals: Growth, parasitism, and history in an estuarine snail population. Journal of the Marine Biological Association of the United Kingdom, 80, 811820.

Da Ros, L., M. G. Marin, N. Nesto, \& S. E. Ford. (1998). Preliminary results of a field study on some stress-related parameters in Tapes philippinarum naturally infected by the protozoan Perkinsus sp. Marine Environmental Research, 46, 249-252.

Daskalakis, K. D. (1996). Variability of metal concentrations in oyster tissue and implications to biomonitoring. Marine Pollution Bulletin, 32, 794-801.

Ellis, M. S., R. D. Barber, R. E. Hillman, \& E. N. Powell. (1998a). Gonadal analysis. In G. G. Lauenstein \& A. Y. Cantillo. Sampling and analytical methods of the National Status and Trends Program Mussel Watch Projects: 


\section{ACCEPTED MANUSCRIPT}

Final xDraft - September 11, $2007 \quad 32$

1993-1996 update. National Oceanic and Atmospheric Administration Technical Memorandum, NOS/ORCA, 130, 216-227.

Ellis, M. S., R. D. Barber, R. E. Hillman, Y. Kim, \& E. N. Powell. (1998b). Histopathology analysis. In G. G. Lauenstein \& A. Y. Cantillo. Sampling and analytical methods of the National Status and Trends Program Mussel Watch Projects: 1993-1996 update. National Oceanic and Atmospheric Administration Technical Memorandum, NOS/ORCA, 130, 198-215.

Ellis, M. S., K-S. Choi, T. L. Wade, E. N. Powell, T. J. Jackson, \& D. H. Lewis. (1993). Sources of local variation in polynuclear aromatic hydrocarbon and pesticide body burden in oysters (Crassostrea virginica) from Galveston Bay, Texas. Comparative Biochemistry and Physiology C Comparative Pharmacology and Toxicology, 106, 689-698.

Farley, C. A. (1976). Ultrastructural observations on epizootic neoplasia and lytic virus infection in bivalve mollusks. Progress in Experimental Tumor Research, 20, $283-294$.

Farrington, J. W., E. D. Goldberg, R. W. Risebrough, J. H. Martin, \& V. T. Bowen. (1983). US Mussel Watch 1976-1978: An overview of the trace metal, DDE, PCB, hydrocarbon and artificial radionuclide data. Environmental Science and Technology, 17, 490-496.

Ford, S. E. (1988). Host-parasite interactions in eastern oysters selected for resistance to Haplosporidium nelsoni (MSX) disease: Survival mechanisms against a natural pathogen. In W. S. Fisher. Disease processes in marine bivalve molluscs. American Fisheries Society Special Publications, 18, 206-224.

Ford, S. E., \& A. J. Figueras. (1988). Effects of sublethal infection by the parasite Haplosporidium nelsoni (MSX) on gametogenesis, spawning, and sex ratios of oysters in Delaware Bay, U.S.A. Diseases of Aquatic Organisms, 4, 121-133.

Ford, S., E. Powell, J. Klinck, \& E. Hofmann. (1999). Modeling the MSX parasite in eastern oyster (Crassostrea virginica) populations. I. Model development, implementation, and verification. Journal of Shellfish Research, 18, 475-500.

Ford, S. E., \& M. R. Tripp. (1996). Diseases and defense mechanisms. In V. 


\section{ACCEPTED MANUSCRIPT}

Final xDraft - September 11, $2007 \quad 33$

S. Kennedy, R. I. E. Newell, \& A. F. Eble. The Eastern Oyster: Crassostrea virginica. (pp. 581-659) College Park, MD: Maryland Sea Grant College Program.

Fraysse, B., J-P. Baudin, J. Garnier-Laplace, C. Adam, \& A. Boudou. (2002). Effects of $\mathrm{Cd}$ and $\mathrm{Zn}$ waterborne exposure on the uptake and depuration of ${ }^{57} \mathrm{Co}$, ${ }^{110 m} \mathrm{Ag}$ and ${ }^{134} \mathrm{Cs}$ by the Asiatic clam (Corbicula fluminea) and the zebra mussel (Dreissena polymorpha)-whole organism study. Environmental Pollution, 118, 297-306.

Galli, P., G. Crosa, L. Mariniello, M. Ortis, \& S. D’Amelio. (2001). Water quality as a determinant of the composition of fish parasite communities. Hydrobiologia, 452, 173-179.

Goldberg, E. D., V. T. Bowen, J. W. Farrington, G. Harvey, J. H. Martin, P. L. Parker, R. W. Risebrough, W. Robertson, E. Schneider, \& E. Gamble. (1978). The Mussel Watch. Environmental Conservation, 5, 101-125.

Goldberg, E. D., M. Koide, V. Hodge, A. R. Flegal, \& J. Martin. (1983). U.S. Mussel Watch: 1977-1978 results on trace metals and radionuclides. Estuarine, Coastal and Shelf Science, 16, 69-93.

Gold-Bouchot, G., R. Simá-Alvarez, O. Zapata-Pérez, \& J. Güemez-Ricalde. (1995). Histopathological effects of petroleum hydrocarbons and heavy metals on the American oyster (Crassostrea virginica) from Tabasco, Mexico. Marine Pollution Bulletin, 31, 439-445.

Green, R. H., R. C. Bailey, S. G. Hinch, J. L. Metcalfe, \& V. H. Young. (1989). Use of freshwater mussels (Bivalvia: Unionidae) to monitor the nearshore environment of lakes. Journal of Great Lakes Research, 15, 635-644.

Green, R. H., J. M. Boyd, \& J. S. MacDonald.. (1993). Relating sets of variables in environmental studies: The sediment quality triad as a paradigm. Environmetrics, 4, 439-457.

Green, R. H., S. M. Singh, \& R. C. Bailey. (1983). Bivalve molluses as response systems for modelling spatial and temporal environmental patterns. Science of the Total Environment, 46, 147-169. 


\section{ACCEPTED MANUSCRIPT}

Final xDraft - September 11, $2007 \quad 34$

Greig, R. A., B. A. Nelson, \& D. A. Nelson. (1975). Trace metal content in the American oyster. Marine Pollution Bulletin, 6, 72-73.

Griffiths, R. W., D. W. Schloesser, J. H. Leach, \& W. P. Kovalak. (1991). Distribution and dispersal of the zebra mussel (Dreissena polymorpha) in the Great Lakes Region. Canadian Journal of Fisheries and Aquatic Sciences, 48 , 1381-1388.

Guth, D. J., H. D. Blankespoor, \& J. Cairns Jr. (1977). Potentiation of zinc stress caused by parasitic infection of snails. Hydrobiologia, 55, 225-229.

Hagopian-Schlekat, T., G. T. Chandler, \& T. J. Shaw. (2001). Acute toxicity of five sediment-associated metals, individually and in a mixture, to the estuarine meiobenthic harpacticoid copepod Amphiascus tenuiremis. Marine Environmental Research, 51, 247-264.

Hall Jr., C.A. (1964). Shallow-water marine climates and molluscan provinces. Ecology, 45, 226-234.

Hawkins, B. A. (1990). Global patterns of parasitoid assemblage size. Journal of Animal Ecology, 59, 57-72.

Hebert, P. D. N., B. W. Muncaster, \& G. L. Mackie. (1989). Ecological and genetic studies on Dreissena polymorpha (Pallas): A new mollusc in the Great Lakes. Canadian Journal of Fisheries and Aquatic Sciences, 46, 1587-1591.

Heinonen, J., J. V. K. Kukkonen, \& I. J. Holopainen. (2001). Temperature- and parasite-induced changes in toxicity and lethal body burdens of pentachlorophenol in the freshwater clam Pisidium amnicum. Environmental Toxicology and Chemistry, 20, 2778-2784.

Hilbish, T. J., A. Mullinax, S. I. Dolven, A. Meyer, R. K. Koehn, \& P. D. Rawson. (2000). Origin of the antitropical distribution pattern in marine mussels (Mytilus spp.): Routes and timing of transequatorial migration. Marine Biology (Berlin), $136,69-77$.

Hinch, S. G., \& R. H. Green. (1989). The effects of source and destination on growth and metal uptake in freshwater clams reciprocally transplanted among 


\section{ACCEPTED MANUSCRIPT}

Final xDraft - September 11, $2007 \quad 35$

south central Ontario lakes. Canadian Journal of Zoology, 67, 855-863.

Hinton, D. E., P. C. Baumann, G. R. Gardner, W. E. Hawkins, J. D. Hendricks, R. A. Murchelano, \& M. S. Okihiro. (1992). Histopathologic biomarkers. In R. J. Huggett, R. A. Kimerle, P. M. Mehrle Jr., \& H. L. Bergman. Biomarkers: Biochemical, physiological, and histological markers of anthropogenic stress. (pp. 155-209) Boca Raton, Florida: CRC Press.

His, E., R. Beiras, \& M. N. L. Seaman. (2000). The assessment of marine pollution - bioasssays with bivalve embryos and larvae. Advances in Marine Biology, 37, 3-178.

Hofmann, E. E., J. M. Klinck, E. N. Powell, S. Boyles, \& M. Ellis. (1994). Modeling oyster populations II. Adult size and reproductive effort. Journal of Shellfish Research, 13, 165-182.

Jackson, T. J., T. L. Wade, J. E. Sericano, J. M. Brooks, J. M. Wong, B. GarciaRomero, \& T. J. McDonald. (1998). Galveston Bay: Temporal changes in the concentrations of trace organic contaminants in National Status and Trends oysters (1986-1994). Estuaries, 21, 718-730.

Johnson, L. L, C. M. Stehr, O. P. Olson, M. S. Myers, S. M. Pierce, B. B. McCain, \& U. Varanasi. (1992). National benthic surveillance project: Northeast coast. Fish histopathology and relationships between lesions and chemical contaminants (1987-89). National Oceanic and Atmospheric Administration Technical Memorandum, NMFS-NWFSC-4, 1-95.

Jones, K. S., D. Herod, \& D. Huffman. (1991). Fitting the negative binomial distribution to parasitological data. Texas Journal of Science, 43, 357-371.

Jovanovich, M. C., \& K. R. Marion. (1987). Seasonal variation in uptake and depuration of anthracene by the brackish water clam Rangia cuneata. Marine Biology (Berlin), 95, 395-403.

Kennedy, C. J., \& P. J. Walsh. (1997). Effects of temperature on xenobiotic metabolism. In C. M. Wood \& D. G. McDonald. Global warming: Implications for freshwater and marine fish. (pp. 303-324) Cambridge, UK: Cambridge University Press. 


\section{ACCEPTED MANUSCRIPT}

Final xDraft - September 11, $2007 \quad 36$

Khan, R. A., \& J. Kiceniuk. (1983). Effects of crude oil on the gastrointestinal parasites of two species of marine fish. Journal of Wildlife Diseases, 19, 253-258.

Kim, Y., \& E. N. Powell. (2004). Surfclam histopathology survey along the Delmarva mortality line. Journal of Shellfish Research, 23, 429-441.

Kim, Y., \& E. N. Powell. (2006). Relationships among parasites and pathologies in sentinel bivalves: NOAA Status and Trends "Mussel Watch" Program. Bulletin of Marine Science, 79, 83-112.

Kim, Y., \& E. N. Powell. (in press). Distribution of parasites and pathologies in sentinel bivalves: NOAA Status and Trends "Mussel Watch" Program. Journal of Shellfish Research.

Kim, Y., E. N. Powell, \& K. A. Ashton-Alcox. (2006). Chapter 2. Histopathology analysis. In: Kim, Y., K. A. Ashton-Alcox and E. N. Powell, Eds., Histological techniques for marine bivalve molluses: Update. National Oceanic and Atmospheric Administration Technical Memorandum NOS NCCOS 27, 19-52.

Kim, Y., E. N. Powell, T. L. Wade, B. J. Presley, \& J. M. Brooks. (2001). The geographic distribution of population health and contaminant body burden in Gulf of Mexico oysters. Archives of Environmental Contamination and Toxicology, 41, 30-46.

Kim, Y., E. N. Powell, T. L. Wade, B. J. Presley, \& J. Sericano. (1998). Parasites of sentinel bivalves in the NOAA Status and Trends Program: Distribution and relationship to contaminant body burden. Marine Pollution Bulletin, 37, 45-55.

Koehn, R. K. (1991). The genetics and taxonomy of species in the genus Mytilus. Aquaculture, 94, 125-145.

Kraak, M. H. S., \& C. Davids. (1991). The effect of the parasite Phyllodistomum macrocotyle (Trematoda) on heavy metal concentrations in the freshwater mussel Dreissena polymorpha. Netherlands Journal of Zoology, 41, 269-276.

Ladrón de Guevara, B., F. Winkler, F. Rodríguez-Romero, \& C. Palma-Rojas. (1996). Comparative karyology of four American oyster species. Veliger, 39, $260-266$. 


\section{ACCEPTED MANUSCRIPT}

Final xDraft - September 11, $2007 \quad 37$

Lafferty, K. D., \& A. M. Kuris. (1999). How environmental stress affects the impacts of parasites. Limnology and Oceanography, 44, 925-931.

Laird, M. (1961). Microecological factors in oyster epizootics. Canadian Journal of Zoology, 39, 449-485.

Landsberg, J. H. (1996). Neoplasia and biotoxins in bivalves: Is there a connection? Journal of Shellfish Research, 15, 203-230.

LaPègue, S., I. Boutet, A Leitão, S. Heurtebise, P. Garcia, C. Thiriot-Quiévreux, \& P. Boudry. (2002). Trans-Atlantic distribution of a mangrove oyster series revealed by $16 \mathrm{~S}$ mtDNA and karyological analyses. Biological Bulletin (Woods Hole), 202, 232-242.

Lauenstein, G. G., \& A. Y. Cantillo. (1993). Sampling and Analytical Methods of the National Status and Trends Program National Benthic Surveillance and Mussel Watch Projects: 1984-1992. Vol. III-IV, National Oceanic and Atmospheric Administration Technical Memorandum, NOS/ORCA 71.

Lauenstein, G. G., \& A. Y. Cantillo. (1998). Sampling and Analytical Methods of the National Status and Trends Program Mussel Watch Projects: 19931996 Update. National Oceanic and Atmospheric Administration Technical Memorandum, NOS/ORCA 130.

Lauenstein, G. G., A. Y. Cantillo, S. Kokkinakis, S. Frew, H. J. Jobling, \& R. R. Fay. (1997). Mussel Watch Project site descriptions through 1997. National Oceanic and Atmospheric Administration Technical Memorandum, NOAA/NOS/ORCA 112, 1-354.

Lee, J-H., P. F. Landrum, \& C-H. Koh. (2002). Prediction of time-dependent PAH toxicity in Hyalella azteca using a damage assessment model. Environmental Science and Technology, 36, 3131-3138.

Lee, R. F., R. Sauerheber, \& A. A. Benson. (1972). Petroleum hydrocarbons: uptake and discharge by the marine mussel Mytilus edulis. Science (Washington, D.C.), 177, 344-346.

Long, E. R., D. D. MacDonald, S. L. Smith, \& F. D. Calder. (1995). Incidence of 


\section{ACCEPTED MANUSCRIPT}

Final xDraft - September 11, 2007 38

adverse biological effects within ranges of chemical concentrations in marine and estuarine sediments. Environmental Management, 19, 81-97.

Lowe, D. M., \& M. N. Moore. (1979). The cytology and occurrence of granulocytomas in mussels. Marine Pollution Bulletin, 10, 137-141.

Lowe, J. I., P. D. Wilson, A. J. Rick, \& A. J. Wilson. Jr. (1971). Chronic exposure of oysters to DDT, toxaphene and parathion. Proceedings of the National Shellfisheries Association, 61, 71-79.

MacKenzie, K., H. H. Williams, B. Williams, A. H. McVicar, \& R. Siddall. (1995). Parasites as indicators of water quality and the potential use of helminth transmission in marine pollution studies. Advances in Parasitology, 35, 85-114.

Mackin, J. G. (1951). Histopathology of infection of Crassostrea virginica (Gmelin) by Dermocystidium marinum Mackin, Owen, and Collier. Bulletin of Marine Science of the Gulf and Caribbean, 1, 72-87.

May, B., \& J. E. Marsden. (1992). Genetic identification and implications of another invasive species of dreissenid mussel in the Great Lakes. Canadian Journal of Fisheries and Aquatic Sciences, 49, 1501-1506.

McDonald, J. H., \& R. K. Koehn. (1988). The mussels Mytilus galloprovincialis and M. trossulus on the Pacific coast of North America. Marine Biology (Berlin), 99, 111-118.

McDowell, J. E., B. A. Lancaster, D. F. Leavitt, P. Rantamaki, \& B. Ripley. (1999). The effects of lipophilic organic contaminants on reproductive physiology and disease processes in marine bivalve molluscs. Limnology and Oceanography, 44, 903-909.

Mills, E. L., M. D. Scheuerell, D. L. Strayer, \& J. T. Carlton. (1996). Exotic species in the Hudson River Basin: A history of invasions and introductions. Estuaries, $19,814-823$.

Möller, H. (1987). Pollution and parasitism in the aquatic environment. International Journal of Parasitology, 17, 353-361.

Mollison, D., \& S. A. Levin. (1995). Spatial dynamics of parasitism. In B. T. 


\section{ACCEPTED MANUSCRIPT}

Final xDraft - September 11, $2007 \quad 39$

Grenfell \& A. P. Dobson. Ecology of infectious diseases in natural populations. (pp. 384-398) Cambridge, UK: Cambridge University Press.

Moore, M. N., J. Widdows, J. J. Cleary, R. K. Pipe, P. N. Salkeld, P. Donkin, S. V. Farrar, S. V. Evans, \& P. E. Thomson. (1984). Responses of the mussel Mytilus edulis to copper and phenanthrene: Interactive effects. Marine Environmental Research, 14, 167-183.

Munger, J. C., W. H. Karasov, \& D. Chang. (1989). Host genetics as a cause of overdispersion of parasites among hosts: How general a phenomenon? Journal of Parasitology, 75, 707-710.

Murphy, S. D. (1980). Assessment of the potential for toxic interactions among environmental pollutants. In C. L. Galli, S. D. Murphy, \& R. Paoletti. The principles and methods in modern toxicology. (pp. 277-294) Amsterdam, The Netherlands: Elsevier/North-Holland Biomedical Press.

Neff, J. M., R. E. Hillman, R. S. Carr, R. L. Buhl, \& J. I. Lahey. (1987). Histopathologic and biochemical responses in arctic marine bivalve molluses exposed to experimentally spilled oil. Arctic, 40 (suppl. 1), 220-229.

Newball, S., \& M. R. Carriker. (1983). Systematic relationship of the oysters Crassostrea rhizophorae and $C$. virginica: A comparative ultrastructural study of the valves. Bulletin of the American Malacological Union, 1, 35-42.

O'Connor, T. P. (1994). The National Oceanic and Atmospheric Administration (NOAA) National Status and Trends Mussel Watch Program: National monitoring of chemical contamination in the coastal United States. In C. R. Cothern \& N. P. Ross. Environmental statistics, assessment, and forecasting. (pp. 331-349) Boca Raton, FL: Lewis Publishers.

O'Connor, T. P. (1996). Trends in chemical concentrations in mussels and oysters collected along the U.S. coast from 1986 to 1993. Marine Environmental Research, 41, 183-200.

O'Connor, T. P. (1998). Mussel Watch results from 1986 to 1996. Marine Pollution Bulletin, 37, 14-19. 


\section{ACCEPTED MANUSCRIPT}

Final xDraft - September 11, $2007 \quad 40$

O’Connor, T. P. (2002). National distribution of chemical concentrations in mussels and oysters in the USA. Marine Environmental Research, 53, 117-143.

O'Connor, T. P., \& C. N. Ehler. (1991). Results from the NOAA National Status and Trends Program on distribution and effects of chemical contamination in the coastal and estuarine United States. Environmental Monitoring and Assessment, 17, 33-49.

O'Connor, T. P., \& B. Beliaeff. (1995). Recent trends in coastal environmental quality: Results from the Mussel Watch Project. Silver Spring, MD: National Oceanic and Atmospheric Administration.

Oliver, L. M., \& W. S. Fisher. (1999). Appraisal of prospective bivalve immunomarkers. Biomarkers, 4, 510-530.

Palmer, R. E. (1979). A histological and histochemical study of digestion in the bivalve Arctica islandica L. Biological Bulletin (Woods Hole), 156, 115-129.

Palmer, S. J, B. J. Presley, R. J. Taylor, \& E. N. Powell. (1993). Field studies using the oyster Crassostrea virginica to determine mercury accumulation and depuration rates. Bulletin of Environmental Contamination and Toxicology, 51, 464-470.

Pascoe, D., \& P. Cram. (1977). The effect of parasitism on the toxicity of cadmium to the three-spined stickleback, Gasterosteus aculeatus L. Journal of Fish Biology. $10,467-472$.

Peterson, C. H. (2001). The "Exxon Valdez" oil spill in Alaska: Acute, indirect and chronic effects on the ecosystem. Advances in Marine Biology, 39, 1-103.

Phillips, D. J. H. (1977). The use of biological indicator organisms to monitor trace metal pollution in marine and estuarine environments - a review. Environmental Pollution, 13, 281-317.

Poulin, R., \& S. Morand. (2000). The diversity of parasites. Quarterly Review of Biology, 75, 277- 293.

Powell, E. N., \& M. S. Ellis. (1998). Perkinsus marinus assay. In G. G. Lauenstein \& A. Y. Cantillo. Sampling and analytical methods of the National Status and 


\section{ACCEPTED MANUSCRIPT}

Final xDraft - September 11, $2007 \quad 41$

Trends Program Mussel Watch Projects: $1993-1996$ update. National Oceanic and Atmospheric Administration Technical Memorandum, NOS/ORCA, 130, 228233.

Powell, E. N., R. D. Barber, M. C. Kennicutt II, \& S. E. Ford. (1999). Influence of parasitism in controlling the health, reproduction and $\mathrm{PAH}$ body burden of petroleum seep mussels. Deep-Sea Research I-Oceanographic Research Papers, 46, 2053-2078.

Presley, B. J., G. A. Wolff, R. J. Taylor, \& P. N. Boothe. (2004). Trace elements in Gulf of Mexico oysters, 1986-1999. In R. J. Hill, J. Leventhal, Z. Aizenshtat, M. J. Baedecker, G. Claypool, R. Eganhouse, M. Goldhaber \& K. Peters. Geochemical investigations in earth and space science: A tribute to Isaac R. Kaplan. The Geochemical Society, Publication No. 9, pp. 267-285.

Puckett, G. L., \& K. R. Carman. (2002). Ciliate epibiont effects on feeding, energy reserves, and sensitivity to hydrocarbon contaminants in an estuarine harpacticoid copepod. Estuaries, 25, 372-381.

Rainbow, P. S. (1997). Trace metal accumulation in marine invertebrates: Marine biology or marine chemistry. Journal of the Marine Biological Association of the United Kingdom, 77, 195-210.

Rawson, P. D., S. Hayhurst, \& B. Vanscoyoc. (2001). Species composition of blue mussel populations in the northeastern Gulf of Maine. Journal of Shellfish Research, 20, 31-38.

Reid, S. D., D. G. McDonald, \& C. M. Wood. (1997). Interactive effects of temperature and pollutant stress. In C. M. Wood \& D. G. McDonald. Global warming: Implications for freshwater and marine fish. (pp. 325-349) Cambridge, UK: Cambridge University Press.

Ringwood, A. H., D. E. Connors, \& C. J. Keppler. (1999). Cellular responses of oysters, Crassostrea virginica, to metal-contaminated sediments. Marine Environmental Research, 48, 427-437.

Roesijadi, G., J. S. Young, A. S. Drum, \& J. M. Gurtisen. (1984). Behavior of trace metals in Mytilus edulis during a reciprocal transplant field experiment. Marine 


\section{ACCEPTED MANUSCRIPT}

Final xDraft - September 11, 2007 $\quad 4^{2}$

Ecology Progress Series, 18, 155-170.

Rohde, K. (1993). Ecology of marine parasites: An introduction to marine parasitology. Oxon, UK: Cab International.

Rohde, K. (2002). Ecology and biogeography of marine parasites. Advances in Marine Biology, 43, 1-86.

Rosenberg, G., \& M. L. Ludyanskiy. (1994). A nomenclatural review of Dreissena (Bivalvia: Dreissenidae), with identification of the quagga mussel as Dreissena bugensis. Canadian Journal of Fisheries and Aquatic Sciences, 51, 1474-1484.

Schmidt, V., S. Zander, W. Körting, K. Broeg, H. von Westernhagen, H. Dizer, P. D. Hansen, A. Skouras, \& D. Steinhagen. (2003). Parasites of flounder (Platichthys flesus L.) from the German Bight, North Sea, and their potential use in biological effects monitoring. C. Pollution effects on the parasite community and a comparison to biomarker responses. Helgoländer Marine Research, 57, 262-271.

Seed, R. (1992). Systematics evolution and distribution of mussels belonging to the genus Mytilus: An overview. Bulletin of the American Malacological Union, 9, $123-137$.

Sindermann, C. J. (1979). Pollution associated diseases and abnormalities of fish and shellfish: A review. Fishery Bulletin, 76, 717-749.

Sindermann, C. J. (1983). An examination of some relationships between pollution and disease. Rapports et Procès-Verbaux des Réunions Conseil Permanent International pour l'Exploration de la Mer, 182, 37-43.

Sousa, W. P. (1991). Can models of soft-sediment community structure be complete without parasites? American Zoologist, 31, 821-830.

Sprague, V., \& P. E. Orr. (1952). Studies on Nematopsis. III. N. ostrearum and $N$. prytherchi with special reference to host-parasite relation. National Shellfisheries Association Convention Addresses pp. 26-43.

Sprague, V., \& P. E. Orr. (1955). Nematopsis ostrearum and N. prytherchi (Eugregarinida, Porosporidae) with special reference to the host-parasite relations. 


\section{ACCEPTED MANUSCRIPT}

Final xDraft - September 11, $2007 \quad 43$

Journal of Parasitology, 41, 89-104.

Stein, J. E., \& J. G. Mackin. (1955). A study of the nature of pigment cells of oysters and the relation of their numbers to the fungus disease caused by Dermocystidium marinum. Texas Journal of Science, 7, 422-429.

Stoeckmann, A. (2003). Physiological energetics of Lake Erie dreissenid mussels: A basis for the displacement of Dreissena polymorpha by Dreissena bugensis. Canadian Journal of Fisheries and Aquatic Sciences, 60, 126-134.

Strayer, D. L. (1991). Projected distribution of the zebra mussel, Dreissena polymorpha, in North America. Canadian Journal of Fisheries and Aquatic Sciences, 48, 1389-1395.

Sures, B., R. Siddall, \& H. Taraschewski. (1999). Parasites as accumulation indicators of heavy metal pollution. Parasitology Today, 15, 16-21.

Svärdh, L. (1999). Bacteria, granulocytoma and trematode metacercariae in the digestive gland of Mytilus edulis: Seasonal and interpopulation variation. Journal of Invertebrate Pathology, 74, 275-280.

Svärdh, L., \& K. Johannesson. (2002). Incidence of hemocytes and parasites in coastal populations of blue mussels (Mytilus edulis)-testing correlations with area, season, and distance to industrial plants. Journal of Invertebrate Pathology, 80, $22-28$.

Thomas, F., F. Cezilly, T. de Meeus, A. Crivelli, \& F. Renaud. (1997). Parasitism and ecology of wetlands: A review. Estuaries, 20, 646-654.

Thulin, J. (1989). Can fish parasites be used to monitor pollution? New Zealand Journal of Zoology, 16, 138.

Valentine, J. W. (1966). Numerical analysis of marine molluscan ranges on the extratropical northeastern Pacific shelf. Limnology and Oceanography, 11, 198211.

Valette-Silver, N. J., G. F. Riedel, E. A. Crecelius, H. Windom, R. G. Smith, \& S. S. Dolvin. (1999). Elevated arsenic concentrations in bivalves from the southeast coasts of the USA. Marine Environmental Research, 48, 311-333. 


\section{ACCEPTED MANUSCRIPT}

Final xDraft - September 11, $2007 \quad 44$

Villalba, A., S. G. Mourelle, M. J. Carballal, \& C. López. (1997). Symbionts and diseases of farmed mussels Mytilus galloprovincialis throughout the culture process in the Rías of Galicia (NW Spain). Diseases of Aquatic Organisms, 31, 127-139.

Wallet, M., \& A. Lambert. (1986). Enquête sur la répartition et l'évolution du parasitisme a Bucephalus polymorphus Baer, 1827 chez le mollusque Dreissena polymorpha dans le sud-est de la France. Bulletin des Sociétés de Pêche et de Pisciculture de France, 300, 19-24.

Weinberg, J. R. (1999). Age-structure, recruitment, and adult mortality in populations of the Atlantic surfclam, Spisula solidissima, from 1978-1997. Marine Biology (Berlin), 134, 113-125.

Wells, H. W., \& I. E. Gray. (1960). The seasonal occurrences of Mytilus edulis on the Carolina coast as a result of transport around Cape Hatteras. Biological Bulletin (Woods Hole), 119, 550-559.

Wenzloff, D. R., R. A. Greig, A. S. Merrill, \& J. W. Ropes. (1979). A survey of heavy metals in the surf clam, Spisula solidissima, and the ocean quahog, Arctica islandica, of the mid-Atlantic coast of the United States. Fishery Bulletin, 77, 280-285.

Widdows, J., T. Bakke, B. L. Bayne, P. Donkin, D. R. Livingstone, D. M. Lowe, M. N. Moore, S. U. Evans, \& S. L. Moore. (1982). Responses of Mytilus edulis to the water-accumulated fraction of North Sea oil. Marine Biology (Berlin), 6\%, $15-31$.

Wilson-Ormond, E. A., M. S. Ellis, E. N. Powell, Y. Kim, \& S-I. Li. (2000). Effects of gas-producing platforms on continental shelf megafauna in the northwest Gulf of Mexico: Reproductive status and health. International Review of Hydrobiology, $85,293-323$.

Wilson, E. A., E. N. Powell, T. L. Wade, R. J. Taylor, B. J. Presley, \& J. M. Brooks. (1992). Spatial and temporal distributions of contaminant body burden and disease in Gulf of Mexico oyster populations: The role of local and large-scale climatic controls. Helgoländer Meeresuntersuchungen, 46, 201-235. 
Final xDraft - September 11, $2007 \quad 45$

Winstead, J. T. (1995). Digestive tubule atrophy in eastern oysters, Crassostrea virginica (Gmelin, 1791), exposed to salinity and starvation stress. Journal of Shellfish Research, 14, 105-111.

Wintermyer, M. L., \& K. R. Cooper. (2003). Dioxin/furan and polychlorinated biphenyl concentrations in Eastern oyster (Crassostrea virginica. Gmelin) tissue and the effects on egg fertilization and development. Journal of Shellfish Research, 22, 737-746.

Wonham, M. J. (2004). Mini-review: Distribution of the Mediterranean mussel Mytilus galloprovincialis (Bivalvia: Mytilidae) and hybrids in the northeast Pacific. Journal of Shellfish Research, 23, 535-543.

Yamamoto, T., K. J. Flynn, \& H. Takayama. (2003). Application of a twocompartment one-toxin model to predict the toxin accumulation in Pacific oysters in Hiroshima Bay, Japan. Fisheries Science, 69, 944-950.

Yevich, P. P., \& C. A. Barszcz. (1983). Histopathology as a monitor for marine pollution. Results of histopathological examinations of the animals collected for the US 1976 Mussel Watch Program. Rapports et Procès-Verbaux des Réunions Conseil Permanent International pour l'Exploration de la Mer, 182, 96-102.

Zaroogian, G., P. Yevich, \& S. Anderson. (1993). Effect of selected inhibitors on cadmium, nickel, and benzo( a)pyrene uptake into brown cells of Mercenaria mercenaria. Marine Environmental Research, 35, 41-45.

Zaroogian, G., P. Yevich, \& S. Pavignano. (1989). The role of the red gland in Mercenaria mercenaria in detoxification. Marine Environmental Research, 28, $447-450$.

Zimmerman, S., B. Sures, \& H. Taraschewski. (1999). Experimental studies on lead accumulation in the eel-specific endoparasites Anguillicola crassus (Nematoda) and Paratenuisentis ambiguus (Acanthocephala) as compared with their host, Anguilla anguilla. Archives of Environmental Contamination and Toxicology, 37 , 190-195. 


\section{ACCEPTED MANUSCRIPT}

Final xDraft - September 11, 2007 46

\section{Legends for Figures}

Figure 1. Bay-mean body burdens of $\mathrm{Ag}$, As and $\mathrm{Cd}$. Vertical bars mark sectional boundaries. Great Lakes/Hudson River dreissenid sites, Bays 1-11; East-coast mytilid sites, Bays 12-36; East-coast oyster sites, Bays 37-61; Puerto Rico, Bay 62; Gulf-coast oyster sites, Bays 63-93; West-coast mytilid sites, Bays 94-125; Hawaii, Bay 126. Data for Bays 37 and 38 not included.

Figure 2. Bay-mean body burdens of $\mathrm{Cr}, \mathrm{Cu}$ and Fe. Vertical bars mark sectional boundaries. Great Lakes/Hudson River dreissenid sites, Bays 1-11; East-coast mytilid sites, Bays 12-36; East-coast oyster sites, Bays 37-61; Puerto Rico, Bay 62; Gulf-coast oyster sites, Bays 63-93; West-coast mytilid sites, Bays 94-125; Hawaii, Bay 126. Data for Bays 37 and 38 not included.

Figure 3. Bay-mean body burdens of $\mathrm{Hg}$, $\mathrm{Ni}$ and $\mathrm{Pb}$. Vertical bars mark sectional boundaries. Great Lakes/Hudson River dreissenid sites, Bays 1-11; East-coast mytilid sites, Bays 12-36; East-coast oyster sites, Bays 37-61; Puerto Rico, Bay 62; Gulf-coast oyster sites, Bays 63-93; West-coast mytilid sites, Bays 94-125; Hawaii, Bay 126. Data for Bays 37 and 38 not included.

Figure 4. Bay-mean body burdens of Se, $\mathrm{Zn}$ and naphthalene. Vertical bars mark sectional boundaries. Great Lakes/Hudson River dreissenid sites, Bays 1-11; East-coast mytilid sites, Bays 12-36; East-coast oyster sites, Bays 37-61; Puerto Rico, Bay 62; Gulf-coast oyster sites, Bays 63-93; West-coast mytilid sites, Bays 94-125; Hawaii, Bay 126. Data for Bays 37 and 38 not included.

Figure 5. Bay-mean body burdens of phenanthrene, fluoranthene and pyrene. Vertical bars mark sectional boundaries. Great Lakes/Hudson River dreissenid sites, Bays 1-11; East-coast mytilid sites, Bays 12-36; East-coast oyster sites, Bays 37-61; Puerto Rico, Bay 62; Gulf-coast oyster sites, Bays 63-93; West-coast mytilid sites, Bays 94-125; Hawaii, Bay 126. Data for Bays 37 and 38 not included.

Figure 6. Bay-mean body burdens of chrysene, total PAHs and total DDTs. Vertical bars mark sectional boundaries. Great Lakes/Hudson River dreissenid sites, Bays 1-11; East-coast mytilid sites, Bays 12-36; East-coast oyster sites, Bays 37-61; Puerto Rico, Bay 62; Gulf-coast oyster sites, Bays 63-93; West-coast mytilid 
sites, Bays 94-125; Hawaii, Bay 126. Data for Bays 37 and 38 not included.

Figure 7. Bay-mean body burdens of aldrin, dieldrin and lindane. Vertical bars mark sectional boundaries. Great Lakes/Hudson River dreissenid sites, Bays 1-11; East-coast mytilid sites, Bays 12-36; East-coast oyster sites, Bays 37-61; Puerto Rico, Bay 62; Gulf-coast oyster sites, Bays 63-93; West-coast mytilid sites, Bays 94-125; Hawaii, Bay 126. Data for Bays 37 and 38 not included.

Figure 8. Bay-mean body burdens of mirex, total chlordanes and total PCBs. Vertical bars mark sectional boundaries. Great Lakes/Hudson River dreissenid sites, Bays 1-11; East-coast mytilid sites, Bays 12-36; East-coast oyster sites, Bays 37-61; Puerto Rico, Bay 62; Gulf-coast oyster sites, Bays 63-93; West-coast mytilid sites, Bays 94-125; Hawaii, Bay 126. Data for Bays 37 and 38 not included. 


\section{ACCEPTED MANUSCRIPT}

Final xDraft - September 11, 2007 48

Table 1. Factor load analysis for the four PCAs. PCAs were conducted separately for mytilids and oysters. For each taxon, a parasite/pathology PCA and a contaminant PCA were run. Variables assigned had factor loads $\geq 0.5$ on the indicated factor axis.

\section{Mytilid PCA}

Parasite/Pathology

P1

P2

P3

$\mathrm{P} 4$

P5 body gregaine major pathology rare parasite trematode metacercaria ceroid body gill ciliate gill gregarine

tissue pathology

prokaryotic inclusion

gut ciliate

Contaminant

C1 phenanthrene fluoranthene pyrene chrysene total PAH total chlordane

$\mathrm{C} 2$

$\mathrm{Cu}$

$\mathrm{Hg}$

$\mathrm{Pb}$

mirex total PCB

$\mathrm{C} 3$ total DDT

aldrin

dieldrin total chlordane

$\mathrm{C} 4$

$\mathrm{Cd}$

$\mathrm{Cr}$

Fe

$\mathrm{Ni}$

$\mathrm{Zn}$

C5

$\mathrm{Ag}$

As

$\mathrm{Zn}$

\section{Oyster PCA}

Parasite/Pathology

$\mathrm{P} 1$

$\mathrm{P} 2$

P3

P4

P5 gill gregarine prokaryotic inclusion body gregarine tissue pathology

trematode sporocyst
Perkinsus marinus

major pathology

mantle gregarine

cestode ceroid body

gut ciliate

\section{Contaminant}

C1 phenanthrene fluoranthene pyrene chrysene total PAH total PCB total chlordane

$$
\mathrm{Ag}
$$

$\mathrm{Cd}$

$\mathrm{Cu}$

$\mathrm{Ni}$

$\mathrm{Zn}$

$\mathrm{C} 3$

total DDT

aldrin

dieldrin lindane total chlordane total PCB

$\mathrm{C} 4$

$\mathrm{Cr}$

$\mathrm{Cu}$

$\mathrm{Hg}$

C5

$\mathrm{Fe}$

$\mathrm{Pb}$

Se

mirex 
Final xDraft - September 11, $2007 \quad 49$

Table 2. Results of ANOVAs comparing contaminant (C) factors with parasite/pathology (P) factors derived from PCA analysis of mytilids and oysters. Factor loads are defined in Table 1 . Only comparisons significant at $\alpha \leq 0.05$ are reported.

\begin{tabular}{|c|c|c|c|}
\hline Taxon & $\begin{array}{c}\text { Parasite/ } \\
\text { Pathology } \\
\text { Factor }\end{array}$ & $\begin{array}{c}\text { Contaminant } \\
\text { Factor } \\
\end{array}$ & $\begin{array}{c}\text { Significance } \\
\text { Level } \\
\end{array}$ \\
\hline \multirow[t]{6}{*}{ All Mytilids } & $\mathrm{P} 1$ & $\mathrm{C} 2$ & 0.027 \\
\hline & $\mathrm{P} 1$ & $\mathrm{C} 5$ & 0.015 \\
\hline & $\mathrm{P} 2$ & $\mathrm{C} 2$ & 0.0001 \\
\hline & $\mathrm{P} 2$ & $\mathrm{C} 4$ & 0.0015 \\
\hline & P3 & $\mathrm{C} 1$ & 0.0046 \\
\hline & $\mathrm{P} 4$ & $\mathrm{C} 4$ & 0.0046 \\
\hline \multirow[t]{3}{*}{ East Coast only } & P3 & $\mathrm{C} 1$ & 0.0056 \\
\hline & P3 & $\mathrm{C} 5$ & 0.0049 \\
\hline & $\mathrm{P} 4$ & $\mathrm{C} 4$ & 0.033 \\
\hline West Coast only & $\mathrm{P} 2$ & $\mathrm{C} 1$ & 0.024 \\
\hline \multirow[t]{12}{*}{ All Oysters } & $\mathrm{P} 1$ & $\mathrm{C} 5$ & 0.0018 \\
\hline & $\mathrm{P} 2$ & $\mathrm{C} 5$ & 0.007 \\
\hline & $\mathrm{P} 4$ & $\mathrm{C} 1$ & 0.0029 \\
\hline & $\mathrm{P} 4$ & $\mathrm{C} 2$ & 0.0041 \\
\hline & $\mathrm{P} 4$ & C3 & 0.0015 \\
\hline & P3 & $\mathrm{C} 1$ & 0.028 \\
\hline & P3 & $\mathrm{C} 5$ & 0.017 \\
\hline & $\mathrm{P} 2$ & $\mathrm{C} 5$ & 0.0097 \\
\hline & P3 & C3 & 0.026 \\
\hline & $\mathrm{P} 4$ & $\mathrm{C} 1$ & 0.0001 \\
\hline & $\mathrm{P} 4$ & $\mathrm{C} 2$ & 0.001 \\
\hline & $\mathrm{P} 4$ & $\mathrm{C} 3$ & 0.023 \\
\hline
\end{tabular}


Final xDraft - September 11, $2007 \quad 50$

Table 3. Significance levels for significant ( $\alpha=0.05)$ Spearman's Rank correlation tests on parasite/pathology-contaminant pairs found significant in ANOVA, for all mytilids. Parentheses indicate negative correlations. Factor pairs are defined in Table 1. Significance levels are provided in Table 2. Results of subsequent binomial tests to determine if the correlation is based solely on the co-occurrence of low values are given in the righthand column by a non-significant result.

\section{Spearman's Binomial}

Significance Significance

Factor Pair Contaminant Parasite/Pathology Level Level

$\begin{array}{ccccc}\text { C2-P1 } & \mathrm{Cu} & \text { body gregarine } & (0.0049) & \\ & \mathrm{Cu} & \text { gill gregarine } & (0.0019) & 0.05 \\ \mathrm{Cu} & \text { mantle gregarine } & (0.0016) & \\ \mathrm{Hg} & \text { body gregarine } & (0.0001) & 0.02 \\ \mathrm{Hg} & \text { gill gregarine } & (0.0001) & \\ \mathrm{Hg} & \text { mantle gregarine } & (0.0001) & 0.02 \\ \mathrm{~Pb} & \text { body gregarine } & (0.019) & \\ & \mathrm{Pb} & \text { gill gregarine } & (0.0068) & 0.02 \\ & \text { mirex } & \text { body gregarine } & (0.0004) & \\ & \text { mirex } & \text { gill gregarine } & (0.0002) & \\ & \text { mirex } & \text { mantle gregarine } & (0.0053) & \\ & \mathrm{Zn} & \text { body gregarine } & 0.016 & 0.02 \\ & \mathrm{Zn} & \text { gill gregarine } & 0.0001 & 0.01\end{array}$




\section{ACCEPTED MANUSCRIPT}

Final xDraft - September 11, $2007 \quad 51$

Table 3. continued

Spearman's Binomial

Significance Significance

\begin{tabular}{|c|c|c|c|c|}
\hline Factor Pair & Contaminant & $\underline{\text { Parasite/Pathology }}$ & Level & Level \\
\hline $\mathrm{C} 2-\mathrm{P} 2$ & $\mathrm{Cu}$ & trematode sporocyst & 0.0011 & 0.025 \\
\hline & $\mathrm{Hg}$ & major pathology & 0.036 & \\
\hline & $\mathrm{Hg}$ & tissue pathology & 0.0004 & 0.05 \\
\hline & $\mathrm{Hg}$ & trematode sporocyst & 0.0001 & 0.005 \\
\hline & $\mathrm{Pb}$ & major pathology & 0.003 & \\
\hline & $\mathrm{Pb}$ & tissue pathology & 0.0001 & 0.0005 \\
\hline & $\mathrm{Pb}$ & trematode sporocyst & 0.0001 & 0.005 \\
\hline & mirex & tissue pathology & 0.02 & 0.005 \\
\hline & total PCB & major pathology & 0.0001 & 0.005 \\
\hline & total PCB & tissue pathology & 0.0001 & 0.005 \\
\hline & total PCB & trematode sporocyst & 0.0002 & 0.01 \\
\hline C4-P2 & $\mathrm{Cd}$ & major pathology & $(0.0001)$ & \\
\hline & $\mathrm{Cd}$ & tissue pathology & $(0.0001)$ & 0.005 \\
\hline & $\mathrm{Cd}$ & trematode sporocyst & $(0.0001)$ & 0.02 \\
\hline & $\mathrm{Cr}$ & major pathology & $(0.013)$ & \\
\hline & $\mathrm{Cr}$ & tissue pathology & $(0.013)$ & \\
\hline & $\mathrm{Fe}$ & tissue pathology & $(0.014)$ & \\
\hline & $\mathrm{Ni}$ & tissue pathology & $(0.022)$ & \\
\hline & $2 n$ & major pathology & $(0.0005)$ & \\
\hline & $\mathrm{Zn}$ & tissue pathology & $(0.044)$ & \\
\hline & oranthene & rare parasite & 0.047 & \\
\hline & pyrene & rare parasite & 0.025 & \\
\hline & total PAH & rare parasite & 0.027 & \\
\hline $\mathrm{C} 4-\mathrm{P} 4$ & $\mathrm{Cd}$ & trematode metacercaria & $(0.0001)$ & 0.005 \\
\hline$\infty$ & $\mathrm{Cr}$ & trematode metacercaria & $(0.0004)$ & 0.05 \\
\hline & $\mathrm{Fe}$ & trematode metacercaria & $(0.0001)$ & \\
\hline & $\mathrm{Fe}$ & ceroid body & $(0.0001)$ & 0.01 \\
\hline & $\mathrm{Fe}$ & digestive gland atrophy & 0.035 & \\
\hline & $\mathrm{Ni}$ & trematode metacercaria & $(0.0001)$ & 0.005 \\
\hline & $\mathrm{Zn}$ & trematode metacercaria & $(0.0013)$ & 0.02 \\
\hline
\end{tabular}


Final xDraft - September 11, $2007 \quad 52$

Table 4. Significance levels for significant $(\alpha=0.05)$ Spearman's Rank correlation tests on parasite/pathology-contaminant pairs found significant in ANOVA, for mytilids on the East and West coast. Parentheses indicate negative correlations. Factor pairs are defined in Table 1. Significance levels are provided in Table 2. Results of subsequent binomial tests to determine if the correlation is based solely on the co-occurrence of low values are given in the righthand column by a nonsignificant result.

\section{East Coast}

Spearman's Binomial

Significance Significance

\begin{tabular}{|c|c|c|c|c|}
\hline Factor Pair & Contaminant & Parasite/Pathology & Level & Level \\
\hline C5-P3 & $\mathrm{Ag}$ & rare parasite & $(0.0069)$ & \\
\hline C4-P 4 & $\mathrm{Cr}$ & trematode metacercariae & $(0.0008)$ & 0.05 \\
\hline & $\mathrm{Cr}$ & digestive gland atrophy & 0.0004 & 0.05 \\
\hline & $\mathrm{Fe}$ & trematode metacercariae & $(0.0001)$ & 0.05 \\
\hline & $\mathrm{Fe}$ & ceroid body & $(0.0005)$ & \\
\hline & $\mathrm{Fe}$ & digestive gland atrophy & 0.0038 & 0.05 \\
\hline & $\mathrm{Ni}$ & trematode metacercaria & $(0.0001)$ & 0.05 \\
\hline & $\mathrm{Ni}$ & igestive gland atrophy & 0.028 & \\
\hline & & & $(0.0063)$ & \\
\hline
\end{tabular}

\section{West Coast}

Spearman's Binomial

Significance Significance

\begin{tabular}{|c|c|c|c|c|}
\hline Factor Pair & $\underline{\text { Contaminant }}$ & Parasite/Pathology & Level & Level \\
\hline \multirow[t]{5}{*}{$\mathrm{C} 1-\mathrm{P} 2$} & phenanthrene & major pathology & 0.0001 & 0.02 \\
\hline & fluoranthene & major pathology & 0.0001 & 0.02 \\
\hline & pyrene & major pathology & 0.0001 & 0.005 \\
\hline & chrysene & major pathology & 0.0001 & \\
\hline & total PAH & major pathology & 0.0001 & \\
\hline
\end{tabular}




\section{ACCEPTED MANUSCRIPT}

Final xDraft - September 11, $2007 \quad 59$

Table 5. Significance levels for significant $(\alpha=0.05)$ Spearman's correlation tests on parasite/pathology-contaminant pairs found significant in ANOVA, for all oysters. Parentheses indicate negative correlations. Factor pairs are defined in Table 1. Significance levels are provided in Table 2. Results of subsequent binomial tests to determine if the correlation is based solely on the co-occurrence of low values are given in the righthand column by a non-significant result.

\section{Spearman's Binomial}

Significance Significance

\begin{tabular}{|c|c|c|c|c|}
\hline Factor & $\mathrm{m}$ & Parasite/Pathology & Level & Level \\
\hline C5-P1 & $\mathrm{Pb}$ & gill gregarine & 0.02 & \\
\hline & $\mathrm{Pb}$ & Perkinsus marinus & 0.0088 & \\
\hline & $\mathrm{Se}$ & Perkinsus marinus & 0.033 & 0.01 \\
\hline
\end{tabular}

C5-P2

$\mathrm{Pb}$

major pathology

0.0024

0.005

C1-P4

fluoranthene

cestode

0.031

pyrene

cestode

0.024

pyrene

ceroid body

0.048

total PCB

cestode

$(0.019)$

C2-P4

$\mathrm{Cd}$

tissue pathology

$\mathrm{Cd}$

cestode

(0.0001)

0.005

$\mathrm{Ni}$

$\mathrm{Ni}$

tissue pathology

cestode

(0.0001)

$\mathrm{Zn}$

ceroid body

0.0008

C3-P4

total DDT
aldrin
aldrin
dieldrin
lindane
total PCB

cestode

(0.0009)

0.05

tissue pathology

(0.0011)

cestode

(0.0001)

cestode

$(0.0037)$

0.05

cestode

$(0.0005)$

cestode

(0.019) 
Table 6. Significance levels for significant ( $\alpha=0.05)$ Spearman's Rank correlation tests on parasite/pathology-contaminant pairs found significant in ANOVA, for Gulf oysters. Parentheses indicate negative correlations. Factor pairs are defined in Table 1. Significance levels are provided in Table 2. Results of subsequent binomial tests to determine if the correlation is based solely on the co-occurrence of low values are given in the righthand column by a non-significant result.

Spearman's Binomial

Significance Significance

Factor Pair Contaminant Parasite/Pathology Level Level

\begin{tabular}{cccccc} 
C5-P2 & $\mathrm{Pb}$ & major pathology & 0.0047 & \multirow{2}{*}{0.02} \\
C3-P3 & total DDT & body gregarine & $(0.0001)$ & \\
& dieldrin & body gregarine & $(0.0001)$ & 0.05 \\
& dieldrin & mantle gregrine & $(0.01)$ & \\
& lindane & body gregarine & $(0.0062)$ & \\
& lindane & mantle gregarine & $(0.0091)$ & \\
& total chlordane & body gregarine & $(0.0002)$ & \\
& total chlordane & mantle gregarine & $(0.039)$ & \\
C1-P4 & total PCB & body gregarine & $(0.0084)$ & \\
& phenanthrene & ceroid body & 0.042 & \\
& pyrene & ceroid body & 0.044 & \\
C2-P4 & total PAH & ceroid body & 0.044 & \\
& $\mathrm{Cd}$ & tissue pathology & $(0.0062)$ & \\
& $\mathrm{Cd}$ & cestode & $(0.0001)$ & 0.05 \\
& $\mathrm{Ni}$ & tissue pathology & $(0.011)$ & \\
& $\mathrm{Ni}$ & cestode & $(0.0005)$ & \\
C3-P4 & $\mathrm{Zn}$ & ceroid body & 0.014 & \\
& aldrin & tissue pathology & $(0.012)$ & \\
& aldrin & cestode & $(0.0041)$ & \\
& lindane & cestode & $(0.038)$
\end{tabular}




\section{ACCEPTED MANUSCRIPT}
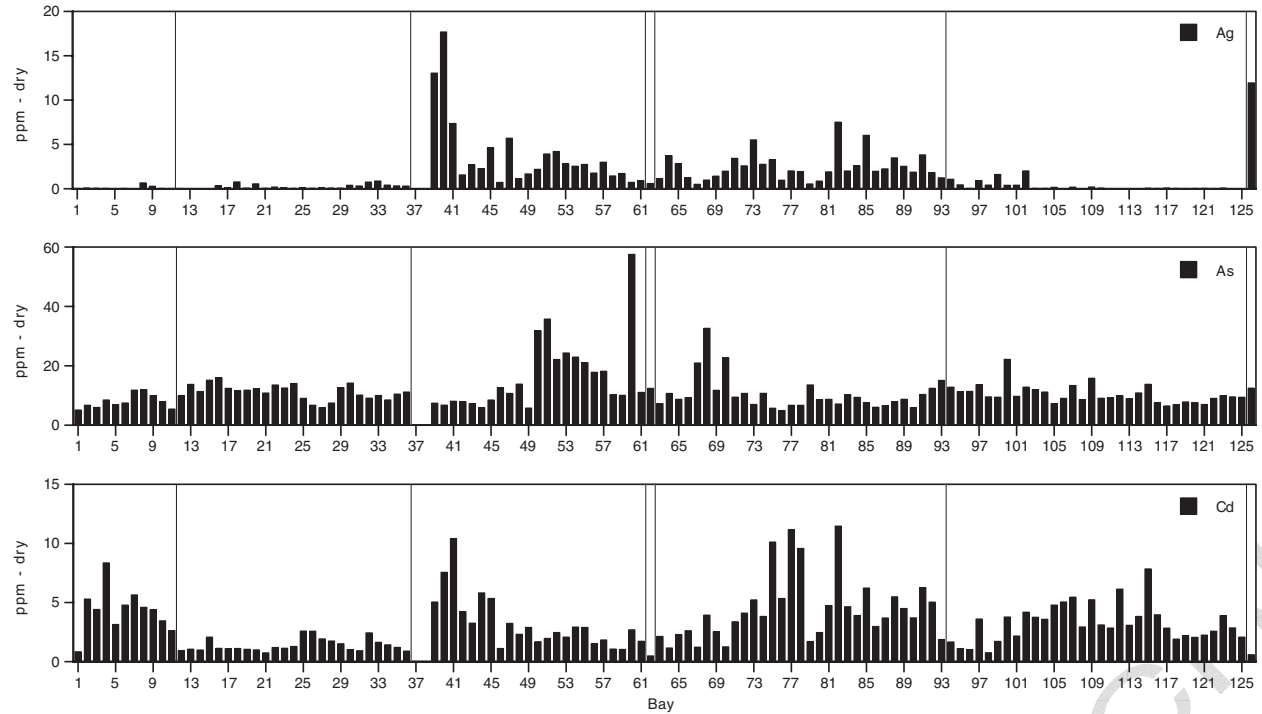

Fig.1
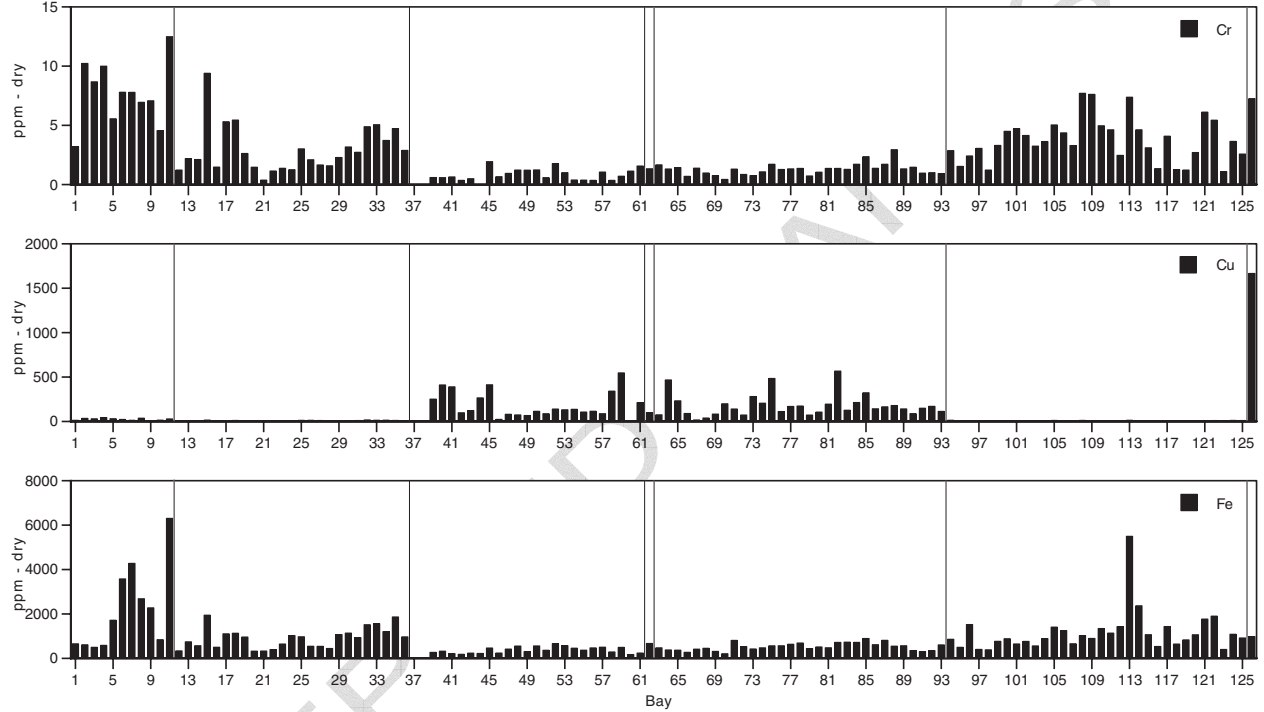

Fig.2 


\section{ACCEPTED MANUSCRIPT}
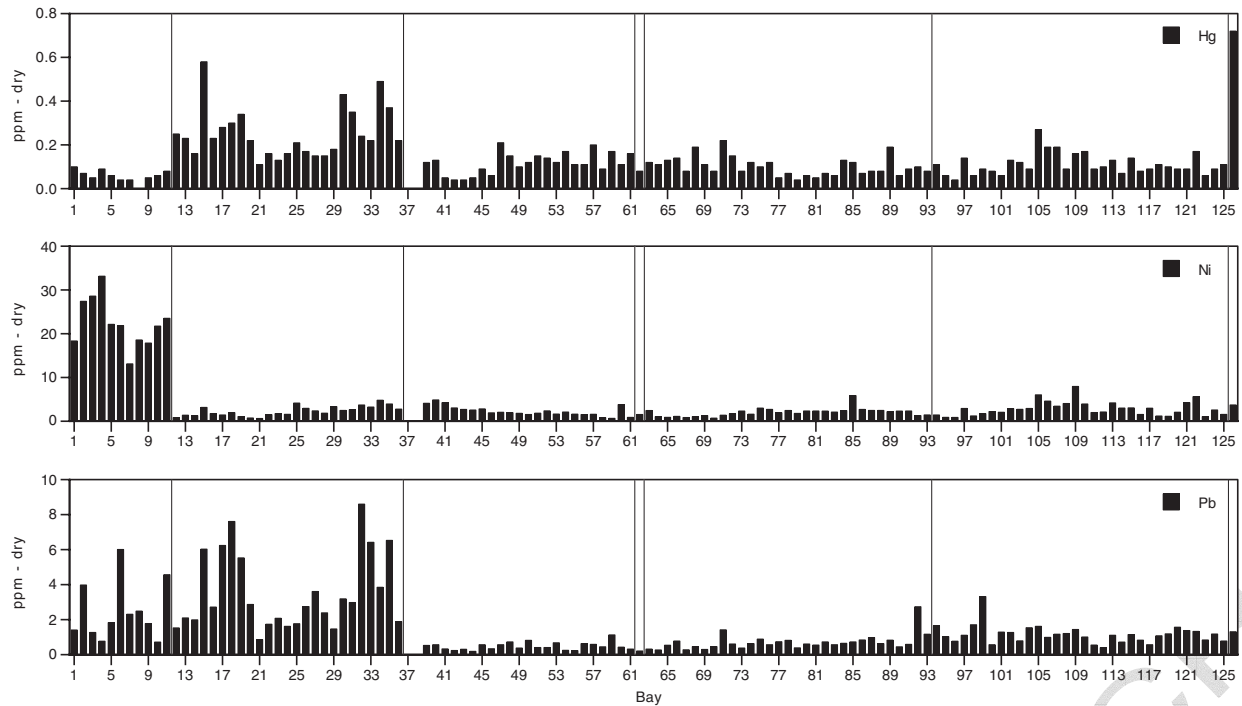

Fig.3
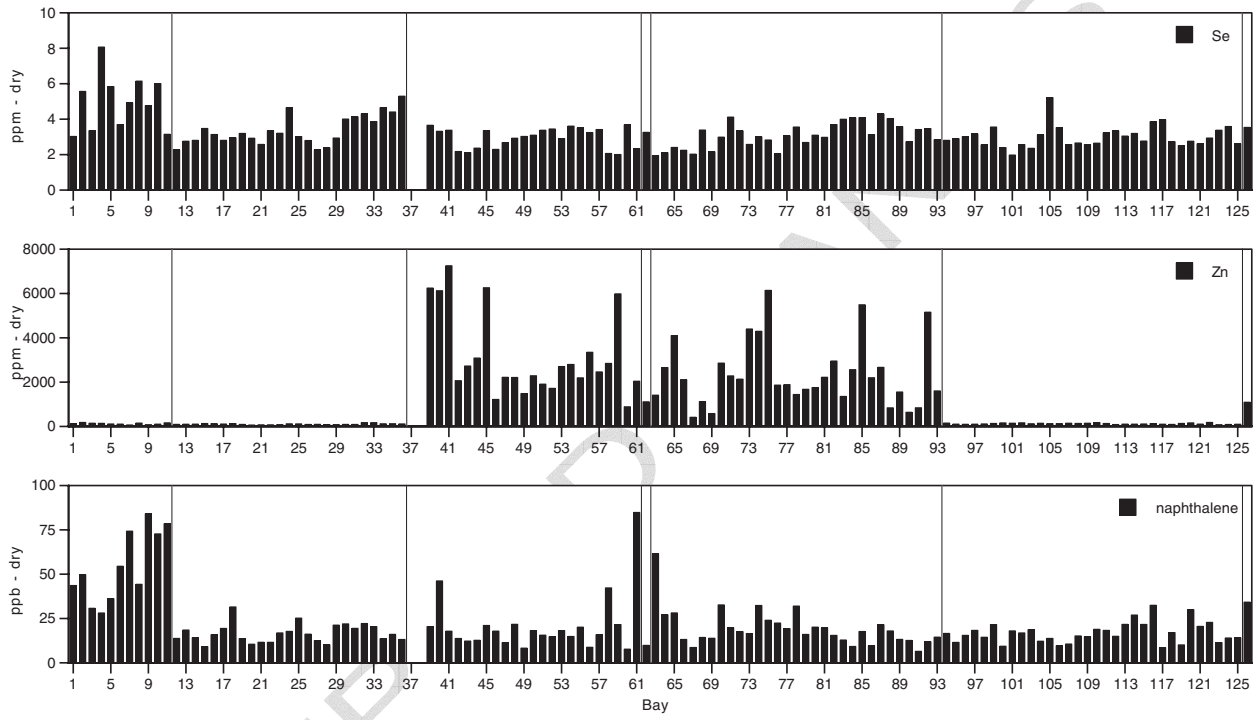

Fig.4 


\section{ACCEPTED MANUSCRIPT}
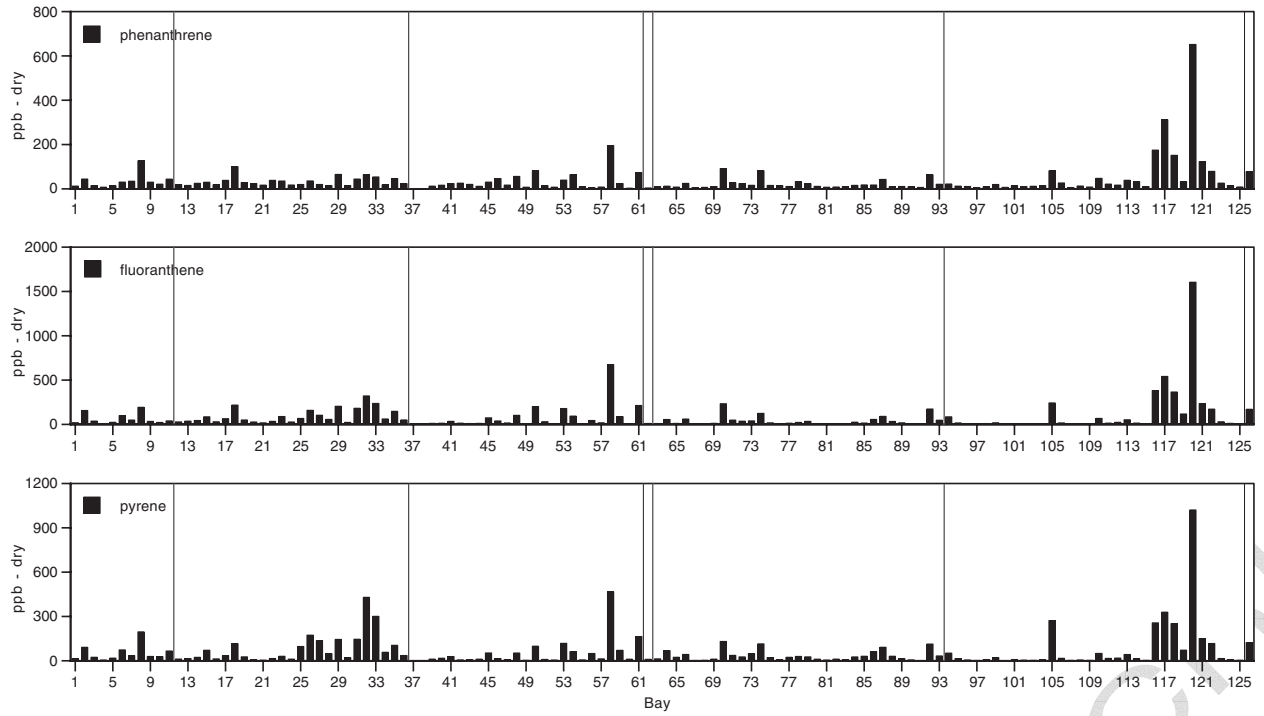

Fig.5
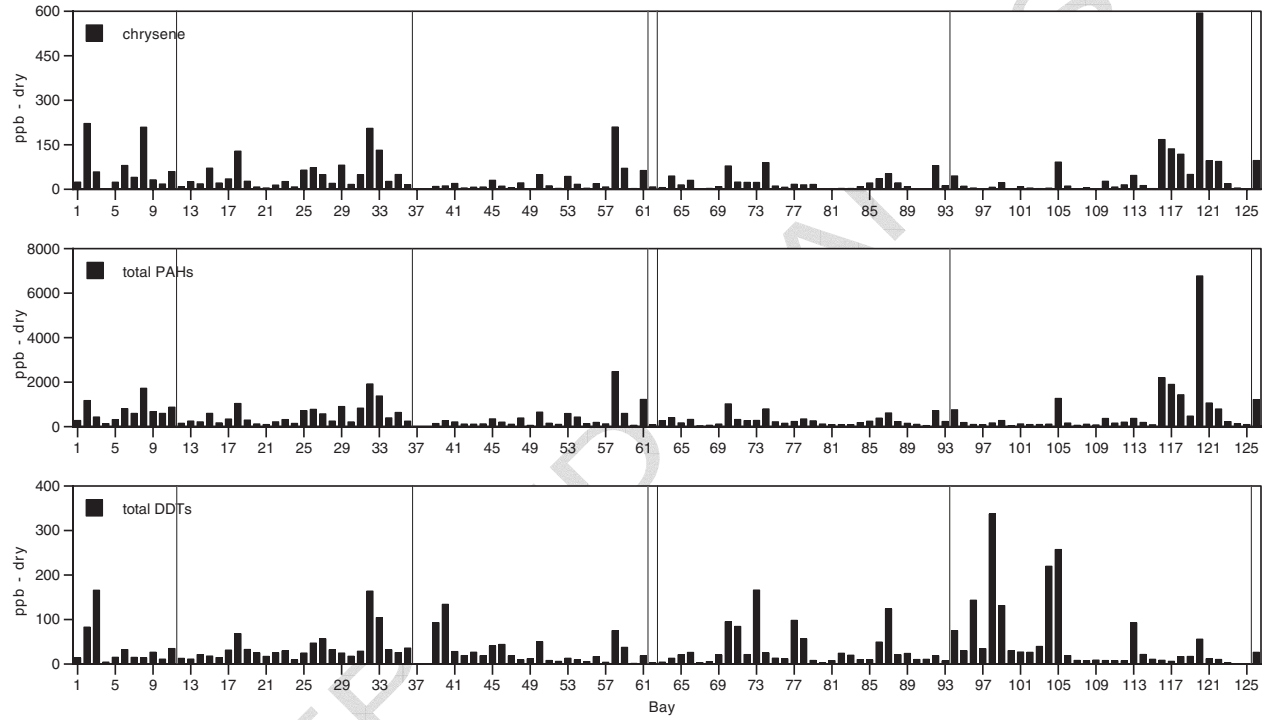

Fig.6 


\section{ACCEPTED MANUSCRIPT}
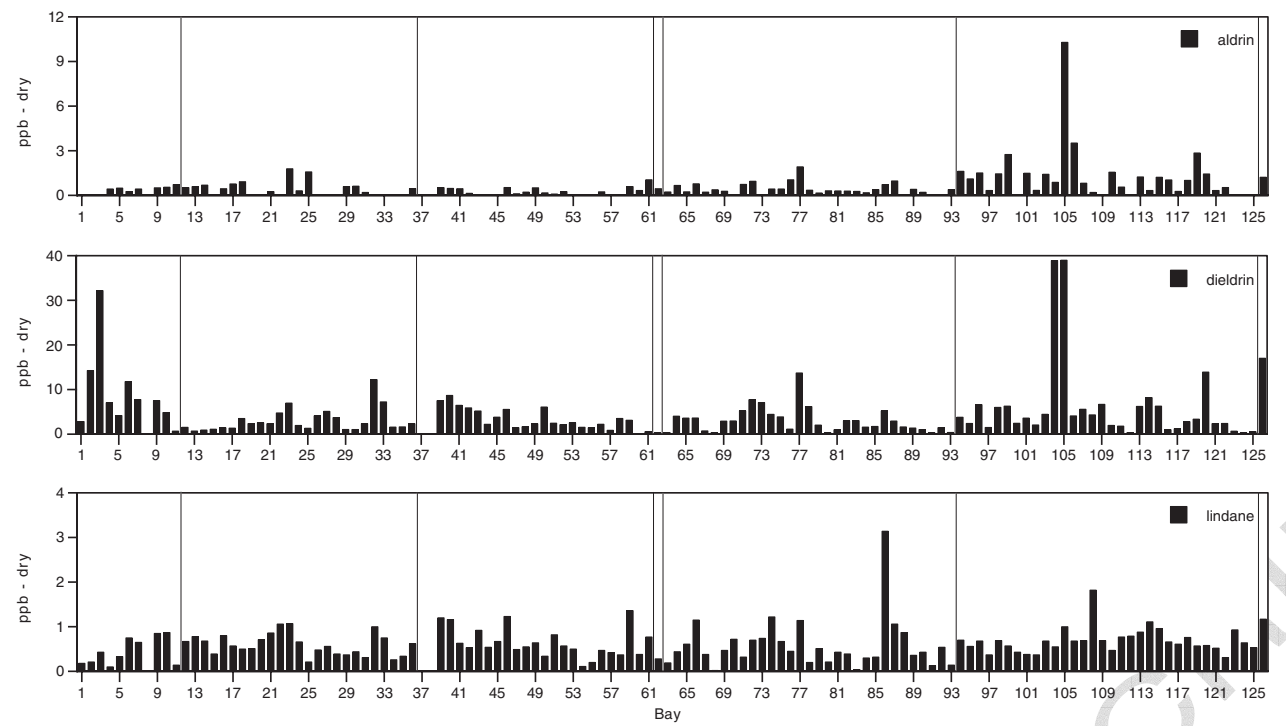

Fig.7
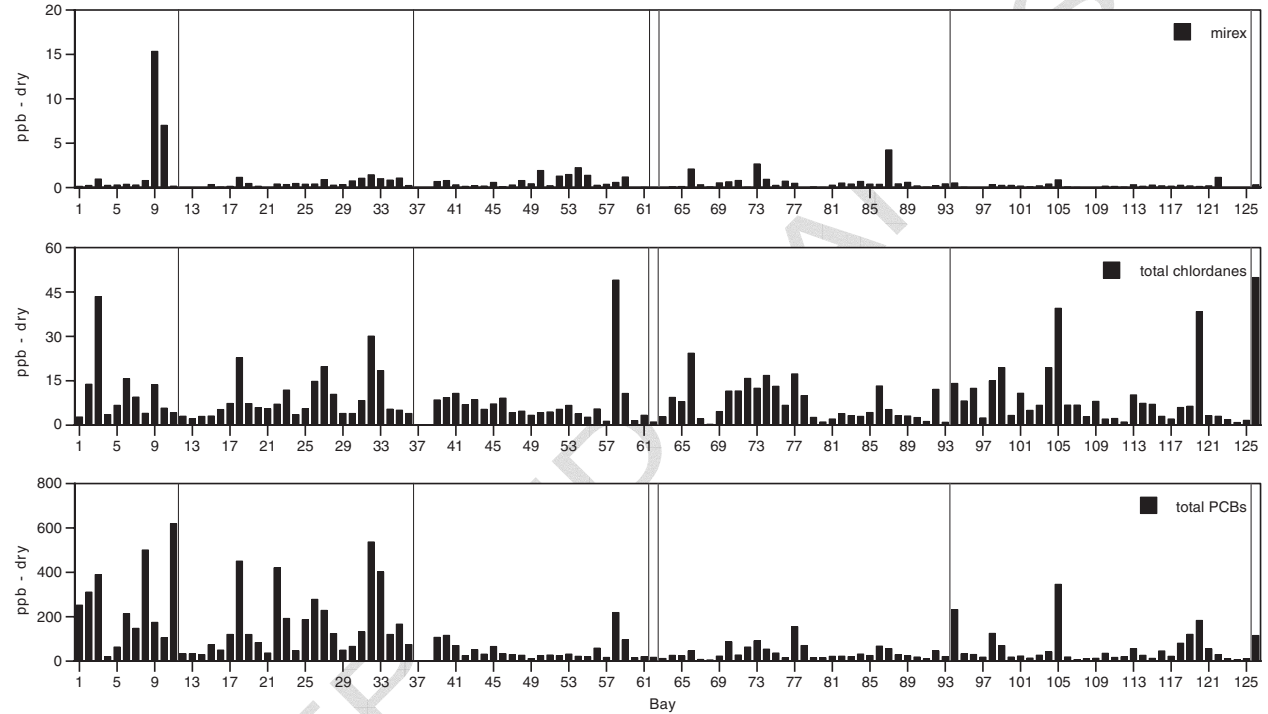

Fig.8 